\title{
PARTIAL SEPARATION OF INDIVIDUAL ENZYME ACTIVITIES OF AN ACP-DEPENDENT FATTY ACID SYNTHETASE FROM BARLEY CHLOROPLASTS
}

\author{
by \\ PETER BORDIER HØJ' ${ }^{1,2}$ and JØRN DALGAARD MIKKELSEN 1,2 \\ IDepartment of Physiology, Carlsberg Laboratory, \\ Gamle Carlsberg Vej 10, DK-2500 Copenhagen Valby \\ 2Institute of Genetics, University of Copenhagen, \\ Øster Farimagsgade 2A, DK-1353 Copenhagen K
}

Keywords: Affinity chromatography, gel filtration, radio-gas liquid chromatography, fatty acids, arsenite, Coenzyme A derivatives, multienzyme complex, monofunctional polypeptide, multifunctional polypeptide.

An acyl carrier protein (ACP) dependent fatty acid synthetase (fas) from barley chloroplast stroma was purified five-fold by ammonium sulphate precipitation and gel filtration on Sephacryl S-300. The $\beta$-ketoacylACP reductase, $\beta$-ketoacyl-ACP synthetase, acetyl-CoA:ACP transacylase and malonyl-CoA:ACP transacylase activities were resolved on the Sephacryl S-300 column with apparent molecular weights of respectively 125,92 , 82 and 41 kilodalton. The fas activity exhibited an apparent molecular weight of 87 kilodalton resulting from the overlapping portions of the component activities. A fifth component of the active fas, ACP, was separated completely from the other four individual enzyme activities by the ammonium sulphate precipitation. When the fas purified by gel filtration was applied to a Mătrex Gel Blue B column, the component activities were separated into two groups. A bound fraction contained all the malonyl-CoA:ACP transacylase whereas the $\beta$-ketoacyl synthetase activity was exclusively present in the non-bound fraction. Neither the bound nor the non-bound fraction showed any fas activity alone, but complete reconstitution of fas activity was obtained when both protein fractions were combined. The barley chloroplast fas is therefore not a multifunctional protein but consists of at least five separable components. Characterization with respect to cofactor requirements was also performed. Variation of certain cofactor concentrations markedly altered the pattern of fatty acid synthesis.

\footnotetext{
Abbreviations: $\mathrm{ACP}=$ acyl carrier protein; DTNB $=5,5$-dithiobis(2-nitro benzoic acid); DTT = 1,4dithiotreitol; Hepes $=\mathrm{N}$-2-hydroxyethylpiperazine-N'-2-ethanesulfonic acid; HPLC $=$ high pressure liquid chromatography; $\mathrm{kD}=$ kilodalton; Tricine $=\mathrm{N}$-(Tris(hydroxy-methyl)-methyl)-glycin; SDS $=$ sodium dodecyl sulphate.
} 


\section{INTRODUCTION}

While the chemistry of fatty acid synthesis seems similar in all organisms, different structural organizations and molecular properties are recognized for the participating enzyme activities. The latter are collectively referred to as fatty acid synthetase (fas) and have been isolated from a number of organisms including yeast, molds, bacteria, animal and plant tissues $(1,2,20,35$, 48,49 ). Based on their structural features these fases can be divided into two major groups. In yeast and animals the catalytic units are multifunctional polypeptides that sediment upon prolonged centrifugation at high g-forces and which can be purified to homogeneity without loss of any of the individual activities necessary for fatty acid synthesis. This form of fas behaves as a single structural and functional unit. By contrast, E.coli fas (1) does not sediment upon prolonged centrifugation, but is composed of a heat stable acyl carrier protein (ACP) and six monofunctional polypeptides which need not be physically associated for in vitro fatty acid synthesis. The requirement for free ACP distinguishes the E.coli fas from the multifunctional multienzyme complex fases. ACP dependent fases have also been described in other bacteria, several plants and algae, but until now the E.coli and E.gracilis fases are the only systems in which the constituent enzymes have been shown to be easily separable. Nevertheless, higher plant fases have generally been assumed to exist as non-associated entities. This hypothesis is based mainly on their ACP dependence and their failure to sediment upon prolonged high speed centrifugation (49). This paper characterizes the soluble ACP dependent fas present in the stroma of barley chloroplasts and presents conclusive evidence that this fas is composed of monofunctional polypeptides separable from one other.

\section{MATERIALS AND METHODS}

\subsection{Biological materials}

Seeds of barley (Hordeum vulgare L. cv. Bonus) were germinated and grown on moist vermiculite at $21^{\circ} \mathrm{C}$ for 6 days in complete darkness. Greening seedlings were obtained by illuminating the dark grown seedlings for 6 hours with Osram L-Fluora model 120-W77 lamps (2400 lux). E.coli strain B was purchased from Calbiochem.

\subsection{Chemicals}

Sodium $\left(1-1^{4} \mathrm{C}\right)$-acetate $\left(61.3 \mathrm{mCi} \cdot \mathrm{mmol}^{-1}\right)$, sodium $(2-14 \mathrm{C})$-malonate $\left(50.9 \mathrm{mCi} \cdot \mathrm{mmol}^{-1}\right)$ and $\left(1-{ }^{14} \mathrm{C}\right.$ )-acetic anhydride $\left(27.7 \mathrm{mCi} \cdot \mathrm{mmol}^{-1}\right)$ were purchased from the Radiochemical Centre (Amersham, England). The 5',5-dithiobis (2-nitrobenzoic acid), (DTNB) came from Fluka. Reduced nicotinamide-adenine dinucleotide phosphate (NADPH), coenzyme A (CoA), adenosine 5'-triphosphate (ATP), N-2-hydroxyethylpiperazine-N'-2-ethanesulfonic acid (Hepes), dithiotreitol (DTT), N-(Tris(hydroxy-methyl)methyl)-glycin (Tricine), cytochrome $c$, hen egg albumin, human transferrin and rabbit muscle aldolase were obtained from Sigma and the reduced form of nicotinamide-adenine dinucleotide (NADH) was a product of the United Breweries (Copenhagen). The Matrex Gel Blue B was from Amicon, while DEAE Sepharose CL 6B, Sephacryl S-300, Sephadex G-10, G-50 and G-75, Blue Sepharose CL 6B, ribonuclease A and chymotrypsinogen $A$ were supplied by Pharmacia, Sweden. The S-malonyl-N-caprylcysteamine was a gift from Dr. JeNs KNUDSEN, University of Odense, Denmark. The Bio-Rad Protein Assay kit was from Bio Rad Laboratories, USA. Ferritin and catalase were products of Boehringer and Worthington Biochemical corporation respectively. Diketene and crotonic anhydride, bovine serum albumin, cellulose thin layer chromatography plates (5552) came from Merck, pantethine from Calbiochem. DEAEcellulose ion exchanger material (DE 52) was supplied by Whatmann. Unless otherwise stated all reagents were analytical grade.

\subsection{Synthesis and purification of substrates}

The $\mathrm{CoA}$ after reduction by $\mathrm{NaBH}_{4}$ and purification by DEAE cellulose chromatography was desalted on a Sephadex G 10 column $(2.5 \times$ $90 \mathrm{~cm}$ ) equilibrated in $3 \mathrm{~mm}-\mathrm{HCl} .(1-14 \mathrm{C}$-acetylCoA was then prepared from the purified CoA and $\left(1-{ }^{4} \mathrm{C}\right)$-acetic anhydride (46), and chromatographed on a DEAE cellulose column (22). $\left(2-{ }^{14} \mathrm{C}\right)$-malonyl-CoA was synthesized (43), the reaction being followed by testing aliquots on 
cellulose TLC plates developed in 1-butanol: acetic acid:water 5:2:3 (v/v/v). The excess CoA was removed by reaction with DTNB (10). Separation of the resulting mixture of $\left(2-1{ }^{4} \mathrm{C}\right)$ malonyl-CoA and the mixed disulfide of DTNBCoA was accomplished by column chromatography using DEAE cellulose (22). The malonyl$\mathrm{CoA}$ fractions were pooled and lyophilized before desalting on a Sephadex G-10 column ( 2.5 $\times 90 \mathrm{~cm}$ ) equilibrated in $3 \mathrm{~mm}-\mathrm{HCl}$. AcetylCoA was prepared by the same procedure as the labelled compound except that acetic anhydride was substituted for the $\left(1-{ }^{14} \mathrm{C}\right)$-acetic anhydride. Malonyl-CoA was prepared from S-malonyl-Ncapryl-cysteamin (12).

Concentrations of all four $\mathrm{CoA}$ derivatives were determined either by measuring the absorbance at 236 and $260 \mathrm{~nm}(12)$ or by measuring free and esterified thiol groups using DTNB (13). The specific activities of $\left(1-{ }^{14} \mathrm{C}\right)$-acetyl-CoA and $\left(2-{ }^{14} \mathrm{C}\right)$-malonyl-CoA were 5.3 and $6.4 \mathrm{mCi}$. $\mathrm{mmol}^{-1}$, respectively. To determine the purity of the ${ }^{14} \mathrm{C}$-labelled substrates high performance liquid chromatography (HPLC) was used (26). That is, the CoA derivatives were chromatographed on a RCM-100 radial PAK-A reversed phase octadecyl column (Waters Assoc., Milford, Mass.). A mobile phase of $50 \mathrm{~mm}$-sodium phosphate ( $\mathrm{pH}$ 5.3):methanol; $23: 2(\mathrm{v} / \mathrm{v})$ was employed (9). The retention times for malonylCoA, CoA and acetyl-CoA were 2.5, 4.7 and $12.7 \mathrm{~min}$, respectively, using a flow rate of 2 $\mathrm{ml} \cdot \mathrm{min}^{-1}$. The HPLC analysis revealed that (2.14 C)-malonyl-CoA comprised more than $98 \%$ of the total radioactivity in the sample. The remaining radioactivity eluted with a retention time of $1.6 \mathrm{~min}$, corresponding to that of free malonic acid. Only trace amounts of free CoA $(<0.5 \%)$ were present. In contrast, $(1-14 \mathrm{C})$ acetyl-CoA contained two contaminating species eluting at 15.2 and $28.4 \mathrm{~min}$. These two peaks contained 33 and $2.8 \%$ of the total radiuactivity, respectively.

Acetoacetyl-pantotheine was synthesized from reduced pantotheine and diketene (39). ACP purified from E.coli (36) was judged by sodium dodecyl sulphate (SDS) polyacrylamide gel electrophoresis to be a homogeneous preparation. Acetyl-ACP, acetoacetyl-ACP and crotonyl$\mathrm{ACP}$ were prepared by reacting reduced $\mathrm{ACP}$ with 100-fold molar excess of acetic anhydride, diketene and crotonic anhydride, respectively (21). Malonyl-ACP was prepared by reacting reduced ACP with 2-fold molar excess of $\mathrm{S}$ malonyl-N-capryl-cysteamin (12).

\subsection{Plastid isolation and enzyme preparations}

Leaves were harvested, wrapped in aluminium foil and cooled on ice. All subsequent procedures were carried out at $4{ }^{\circ} \mathrm{C}$. A total of 2 $\mathrm{kg}$ leaves was homogenized in a blender with replaceable razor blades (27); per $200 \mathrm{~g}$ leaves, $500 \mathrm{ml}$ of media $(0.6 \mathrm{M}$-glycerol; $0.1 \mathrm{M}$-Tricine$\mathrm{NaOH}$ at $\mathrm{pH} 9.0$ ) was used. The homogenate was squeezed through a single layer of $31 \mu \mathrm{m}$ mesh nylon gauze and then filtered through another identical gauze layer. The filtrate was centrifuged for $5 \mathrm{~min}$ in a Sorval RC 2B centrifuge at $4,080 \times \mathrm{g}$, and the plastid pellet was suspended in $45 \mathrm{ml}$ of resuspension medium (0.3 M-glycerol; $0.1 \mathrm{~m}$-Tricine- $\mathrm{NaOH}$ at $\mathrm{pH} 9.0$; 2 mм-DTT; $1 \mathrm{~mm}-\mathrm{MgCl}_{2}$ ). Rupture of plastids was accomplished by passing them through an ice cold Amicon French pressure cell at 8,000 psi. The homogenate obtained was centrifuged at $226,000 \times \mathrm{g}$ for $45 \mathrm{~min}$ in a Beckmann model L5/75 ultracentrifuge using a $\mathrm{Ti} 50$ rotor. Further fractionation of the stroma proteins in the supernatant was achieved by $\left(\mathrm{NH}_{4}\right)_{2} \mathrm{SO}_{4}$ precipitation. $\left(\mathrm{NH}_{4}\right)_{2} \mathrm{SO}_{4}$ was added gradually with stirring to $40 \%$ saturation and the solution left stirring for an additional $30 \mathrm{~min}$, before centrifugation at $10,000 \times \mathrm{g}$ for $30 \mathrm{~min}$. Additional $\left(\mathrm{NH}_{4}\right)_{2} \mathrm{SO}_{4}$ was added to the resulting supernatant until $70 \%$ saturation was obtained. Stirring and centrifugation followed as previously. The $40-70 \%$ precipitate was dissolved in $10 \mathrm{ml}$ suspension medium ( $0.3 \mathrm{M}$-glycerol; 0.1 $\mathrm{M}$-Tricine- $\mathrm{NaOH}$ at $\mathrm{pH}$ 9.0; 2 mM-DTT). Before assaying the $\left(\mathrm{NH}_{4}\right)_{2} \mathrm{SO}_{4}$ precipitated proteins for enzyme activities, they were desalted on a Sephadex G-50 column equilibrated in suspension medium.

\subsubsection{Gel filtration of $40-70 \%\left(\mathrm{NH}_{4}\right)_{2} \mathrm{SO}_{4}$ precipitated stroma proteins}

The $\left(\mathrm{NH}_{4}\right)_{2} \mathrm{SO}_{4}$ fractionated protein solution was layered on top of a $5 \times 91 \mathrm{~cm}$ Sephacryl S-300 column previously equilibrated with suspension medium. The column was eluted 
with a flow rate of $60 \mathrm{ml} \cdot \mathrm{hr}^{-1}$ and the eluate continuously scanned for absorption at $280 \mathrm{~nm}$ using a Model 2089 UVICORD III (LKB Instrument, Sweden). Fractions of $9.5 \mathrm{ml}$ were collected. Those found to contain fas activity were pooled and concentrated by pressure dialysis in an Amicon cell fitted with a PM10 Diaflo ultrafiltration membrane (Amicon, Mass.). Little or no loss of activity occurs during 14 days if the proteins are stored in this concentrated form at $-20{ }^{\circ} \mathrm{C}$. The obtained protein material is subsequently referred to as S-300 fas (protein fraction having fas activity after passage through S-300).

\subsubsection{Fractionation of the $S-300$ fas on Matrex Gel Blue B}

$111 \mathrm{mg}$ of S-300 fas $(35 \mathrm{ml})$ was loaded onto a Mātrex Gel Blue B column $(2.5 \times 12 \mathrm{~cm})$ preequilibrated with suspension medium at a flow rate of $20 \mathrm{ml} \cdot \mathrm{h}^{-1}$. The column was washed with suspension medium until no further proteins could be eluted. The proteins that did not bind (non-bound protein fraction) were concentrated to $20 \mathrm{ml}$ by pressure dialysis using a PM10 membrane. The bound proteins were eluted with suspension medium containing $1 \mathrm{M}-\mathrm{NaCl}$ and subsequently diluted ten-fold with the same medium before concentration with a PM10 membrane to a final volume of $9 \mathrm{ml}$. To obtain an aliquot of non-bound protein completely free of Blue $\mathrm{B}$ bound material, $5 \mathrm{ml}$ of the non-bound protein was reloaded onto the regenerated Blue $B$ column using a flowrate of $12 \mathrm{ml} \cdot \mathrm{h}^{-1}$. The first two thirds of the resulting non-bound protein peak was pooled and concentrated to $19 \mathrm{ml}$ on a PM 10 membrane before carrying out reconstitution experiments. Regeneration of the Blue B column was done by washing the column with 6 $\mathrm{M}$-urea in $0.5 \mathrm{M}-\mathrm{NaOH}$ followed by enough starting buffer to reach the desired $\mathrm{pH}$.

\subsubsection{Preparation of barley $A C P$}

Partially purified ACP was obtained from barley chloroplasts using a slightly modified procedure to that employed by SimoNi et al. (47) for the purification of spinach ACP. After fractionating the isolated stroma proteins to $70 \%\left(\mathrm{NH}_{4}\right)_{2} \mathrm{SO}_{4}$, as detailed above, the final supernatant served as an ACP source either immediately or after storage at $-20^{\circ} \mathrm{C}$. The supernatant was placed in a $90^{\circ} \mathrm{C}$ waterbath for $15 \mathrm{~min}$ and then transferred to an icebath for cooling. The denatured protein was removed by centrifugation. The new supernatant was adjusted to $\mathrm{pH} 1.0$ by addition of concentrated $\mathrm{HCl}$ and left overnight at $4{ }^{\circ} \mathrm{C}$, whereupon the acid precipitable proteins were collected by centrifugation. Pelleted protein was suspended in a minimum volume of $20 \mathrm{~mm}-\mathrm{Hepes}$ at $\mathrm{pH} 7.0$ containing 2 mм-DTT. The solution was adjusted to $\mathrm{pH} 7.0$ with $2 \mathrm{~m}-\mathrm{NaOH}$, thereafter it was homogenized and centrifuged. The tenacious precipitate was discarded and the conductivity of the supernatant adjusted to $5 \mathrm{mS}$ by addition of $20 \mathrm{~mm}$-Hepes at pH 7.0, $2 \mathrm{~mm}$-DTT previous to loading on a DEAE Sepharose CL 6B column $(1.5 \times 10 \mathrm{~cm})$ equilibrated in the same buffer. The column was washed with the buffer until no further absorbing material at $280 \mathrm{~nm}$ eluted, and the ACP was recovered by eluting with a $250 \mathrm{ml}$ linear gradient from 0.0 to $0.7 \mathrm{M}-\mathrm{NaCl}$ in 20 mm-Hepes at $\mathrm{pH}$ 7.0, 2 mm-DTT. Fractions of $2.8 \mathrm{ml}$ were collected with a flowrate of 12 $\mathrm{ml} \cdot \mathrm{h}^{-1}$.

\subsection{Enzyme and protein assays}

\subsubsection{Fatty acid synthetase}

Three radioactively labelled substrates were used to assay activity of the fas. Unless otherwise stated the assay mixture for each labelled substrate was as follows: $\left(1-{ }^{14} \mathrm{C}\right)$-acetate; the assay mixture contained $5.0 \mu \mathrm{mol}$ sodium phosphate buffer at $\mathrm{pH} 7.9,10 \mu \mathrm{mol}$ bicarbonate, $0.082 \mu \mathrm{mol}\left(1-{ }^{14} \mathrm{C}\right)$-acetate $(5 \mu \mathrm{Ci}), 20$ nmol CoA, $2 \mu \mathrm{mol}$ ATP, $0.5 \mu \mathrm{mol}$ NADH, 1.0 $\mu \mathrm{mol}$ NADPH, $50 \mu \mathrm{g}$ E.coli ACP, I $\mu \mathrm{mol}$ $\mathrm{MnCl}_{2}, \quad 1 \mu \mathrm{mol} \mathrm{MgCl}_{2}$ and enzyme plus suspension medium in a final volume of $0.8 \mathrm{ml}$. $\left(2-1^{4} \mathrm{C}\right)$-malonyl-CoA; $64 \mathrm{nmol}$ of $\left(2 .{ }^{4} \mathrm{C}\right)$-malonyl-CoA $(132,000 \mathrm{dpm}), 20 \mathrm{nmol}$ of acetylCoA, $1 \mu \mathrm{mol}$ NADPH, $0.5 \mu \mathrm{mol}$ NADH, $50 \mu \mathrm{g}$ E.coli ACP, $5 \mu \mathrm{mol} 0.1 \mathrm{~m}$-sodium phosphate buffer at $\mathrm{pH} 7.9$ and enzyme plus suspension medium in a final volume of $0.8 \mathrm{ml} .\left(1-{ }^{14} \mathrm{C}\right)$ acetyl-CoA; additions were the same as in the $(2.14 \mathrm{C})$-malonyl-CoA assay except that $64 \mathrm{nmol}$ of cold malonyl-CoA and $11.6 \mathrm{nmol}$ of $(1-14 \mathrm{C})$ acetyl-CoA $(135,000 \mathrm{dpm})$ were used. The latter 
two labelled substrates were used preferentially so as to avoid the question of the presence or absence of active acetyl-CoA synthetase and acetyl-CoA carboxylase which are required when labelled acetate is the precursor. The $\mathrm{pH}$ in the standard assay mixture was 8.7. Reactions were initiated by enzyme addition and after 15 min incubation in a $27^{\circ} \mathrm{C}$ shaking waterbath they were terminated by addition of $1 \mathrm{ml} 40 \%$ (w/v) $\mathrm{KOH}$. Following base hydrolysis at $90^{\circ} \mathrm{C}$ for $30 \mathrm{~min}$, the assay mixtures were acidified by addition of $1 \mathrm{ml} 40 \%(\mathrm{v} / \mathrm{v}) \mathrm{H}_{2} \mathrm{SO}_{4}$. A cold carrier solution of free fatty acids $(20 \mu \mathrm{g}$ each of $\mathrm{C}_{12}, 14,16,18,20$ and 22 ) was added and the fas products extracted with three $\times 3 \mathrm{ml}$ portions of $\mathrm{n}$-hexane or n-pentane. The solvent was evaporated under a stream of nitrogen and the residue dissolved in $1 \mathrm{ml} \mathrm{n}$-hexane. Aliquots of $200 \mu \mathrm{l}$ were transferred to scintillation vials, and $10 \mathrm{ml}$ of Instafluor (United Technologies Packard, Illinois, U.S.A.) was added before quantitation by liquid scintillation counting.

The free fatty acids were converted to their methyl or butyl ester derivatives by reaction with diazomethane or $\mathrm{BF}_{3}$-butanol, respectively. Separation and quantitation of the resulting ester derivatives were performed by radio-gas liquid chromatography analysis as detailed previously (37). Stainless steel columns $(3.2 \mathrm{~mm} \times 152$ $\mathrm{cm})$ containing either Silar 10C on 100/120 mesh Gas-Chrom Q (Applied Science, Pennsylvania) or $5 \% \mathrm{SE} 30$ on $110 / 120$ mesh Anakrom ABS (Analabs) were used with a temperature programme of $2{ }^{\circ} \mathrm{C} \cdot \mathrm{min}^{-1}$ from 150 to $240^{\circ} \mathrm{C}$.

To study the effect of sodium arsenite it was dissolved in suspension medium lacking DTT, and the $\mathrm{pH}$ was adjusted to 8.7 with $2 \mathrm{M}-\mathrm{HCl}$. $400 \mu \mathrm{l}$ fas solution (1.04 mg protein) was preincubated with the appropriate amounts of arsenite for $7 \mathrm{~min}$ at $27^{\circ} \mathrm{C}$. The pre-incubation volume was adjusted to $500 \mu \mathrm{l}$ with suspension buffer. To initiate fatty acid synthesis a mixture of substrates and cofactors dissolved in $100 \mu \mathrm{l}$ was added. Thereafter, the standard procedure using $\left(2 .{ }^{4} \mathrm{C}\right)$-malonyl-CoA for assay of fas as detailed above was carried out. Where stated the spectrophotometric assay as described for fas II by HeNDReN and BLoCH (21) has been used except that equal amounts of NADPH and NADH were employed.

\subsubsection{Acetyl-and malonyl-CoA:ACP transacylases plus barley $A C P$}

The malonyl- and acetyl-CoA:ACP transacylase activities were estimated by allowing the transfer of the respective acyl groups from $\left(2-{ }^{14} \mathrm{C}\right)$-malonyl-CoA or $\left(1-1^{4} \mathrm{C}\right)$-acetyl-CoA to $\mathrm{ACP}$ and measuring the acid precipitable radioactivity (21). The assay mixture for acetylCoA:ACP transacylase contained $50 \mu \mathrm{g} \mathrm{E}$. coli $\mathrm{ACP}, 7.5 \mathrm{nmol}$ of $\left(1-{ }^{14} \mathrm{C}\right)$-acetyl-CoA $(5.3 \mu \mathrm{Ci}$. $\left.\mu \mathrm{mol}^{-1}\right), 5 \mu \mathrm{mol}$ of $0.1 \mathrm{M}$-sodium phosphate buffer at $\mathrm{pH} 7.0,1 \mu \mathrm{mol}$ DTT, $0.1 \mu \mathrm{mol}$ ethyldiaminetetraacetate and enzyme in a total volume of $250 \mu \mathrm{l}$. Incubation time was $10 \mathrm{~min}$ at $27{ }^{\circ} \mathrm{C}$. The assay mixture for malonylCoA:ACP transacylase was similar except for the substitution of $1.6 \mathrm{nmol}$ of $\left(2-1^{4} \mathrm{C}\right)$-malonyl$\mathrm{CoA}\left(6.4 \mu \mathrm{Ci} \cdot \mu \mathrm{mol}^{-1}\right)$ for acetyl-CoA and that the final volume was $100 \mu$. Incubation time was $1 \mathrm{~min}$ at $27^{\circ} \mathrm{C}$. Reactions were initiated by addition of labelled substrate and terminated by addition of $0.4 \mathrm{ml}$ icecold $10 \%$ perchloric acid $(\mathrm{v} / \mathrm{v})$. Then $20 \mu \mathrm{l}$ of $10 \%(\mathrm{w} / \mathrm{v})$ bovine serum albumin was added and the precipitated protein pelleted by centrifugation. The pellet was washed twice with $1.0 \mathrm{ml}$ of icecold $2 \%(\mathrm{v} / \mathrm{v})$ perchloric acid and subsequently dissolved in $0.65 \mathrm{ml} 1 \mathrm{M}$ $\mathrm{NaOH}$. After ten minutes incubation at room temperature the reaction mixture was transferred quantitatively to a scintillation vial. Ten $\mathrm{ml}$ of DIMILUME-30 (United Technologies, Packard) were added before counting.

Large scale labelled transacylase product preparations for use as substrates were prepared by scaling up the above assays 11 -fold. That is, transacylase mixtures were incubated at $30^{\circ} \mathrm{C}$ for $30 \mathrm{~min}$. The acid precipitable proteins were pelleted and washed six times with $1 \mathrm{ml}$ portions of icecold $10 \%(\mathrm{v} / \mathrm{v})$ perchloric acid. The washed pellets were then dissolved in $2 \mathrm{M}$ Tricine at $\mathrm{pH} 9.0$ and immediately thereafter used as a substrate in fas assays. Fractionation of large scale malonyl-CoA:ACP transacylase incubation mixtures was done by gel filtration on a Sephadex G-75 column (1.6 $\times 56$ cm) equilibrated in $10 \mathrm{~mm}$-sodium phosphate at $\mathrm{pH} 7.0,2$ mM-DTT. After $30 \mathrm{~min}$ incubation the reaction mixture was applied directly to the column and eluted with a flow rate of $10 \mathrm{ml} \cdot \mathrm{h}^{-1}$. Fractions of $3.5 \mathrm{ml}$ were collected and aliquots counted in a Model LS 3155T Beckmann scintillation 
counter. The assay mixture for barley $\mathrm{ACP}$ was the same as for malonyl-CoA:ACP transacylase except that $100 \mu \mathrm{l} \mathrm{S-300} \mathrm{fas} \mathrm{and} \mathrm{barley} \mathrm{ACP}$ were used in place of malonyl transacylase and E.coli ACP. The total volume was $250 \mu \mathrm{l}$ and the incubation time $5 \mathrm{~min}$. Results are compared to those for pure E.coli ACP.

\subsection{3. $\beta$-ketoacyl-ACP synthetase}

$\beta$-ketoacyl-ACP synthetase was assayed at 25 ${ }^{\circ} \mathrm{C}$ by measuring the increase in absorbancy at $303 \mathrm{~nm}$ due to formation of acetoacetyl-ACP from acetyl-ACP and malonyl-ACP (21). Reaction mixtures contained 12 nmoles of acetylACP, 14 nmoles of malonyl-ACP, 12 nmoles of $\mathrm{MgCl}_{2}$ and enzyme. Suspension medium was added to give a total volume of $650 \mu \mathrm{l}$. The reaction was initiated by addition of malonylACP, to the sample but not to the blank, and absorbancy changes were measured with an Aminco-Chance-DW-2a dual wavelength recording spectrophotometer against the blank. Under these conditions the assay was linear for more than minutes over a wide range of enzyme concentrations.

\subsection{4. $\beta$-ketoacyl-ACP reductase}

$\beta$-ketoacyl-ACP reductase activity was measured at $25{ }^{\circ} \mathrm{C}$ by following the decrease in absorbancy at $340 \mathrm{~nm}$ due to the NADPH mediated reduction of acetoacetyl-ACP or acetoacetyl-pantotheine (1). Reaction mixtures contained enzyme, $200 \mathrm{nmol}$ of NADPH and 20 $\mathrm{nmol}$ of acetoacetyl-ACP or $510 \mathrm{nmol}$ of acetoacetyl-pantotheine. Suspension medium was added to give a total volume of $650 \mu$. The reaction was initiated by addition of the acetoacetyl derivative to the sample but not to the blank. Absorbancy was determined as described above.

\subsubsection{Protein determination}

Protein was determined by the Lowry procedure (34) using bovine serum albumin as a standard or alternatively according to BRADFORD (6) using a Bio-Rad protein assay kit I with gamma globulin as the standard.
Table I

Cofactor requirements for the fatty acld synthetase isolated from the stroma of barley chloroplasts.

\begin{tabular}{lcc}
\hline Addition & $\begin{array}{c}\text { Total cpma) } \\
\left(\times 10^{-4}\right)\end{array}$ & $\begin{array}{c}\text { \% of } \\
\text { control }\end{array}$ \\
\hline complete & 138 & 100 \\
- ACP & 29 & 21 \\
- ATP & $<1$ & $<1$ \\
- NADPH & 71 & 51 \\
- NADH & 149 & 108 \\
- CoASH & 12 & 9 \\
- MnCl & 137 & 99 \\
- bicarbonate & 138 & 100 \\
\hline
\end{tabular}

a) $(1-14 \mathrm{C})$-acetate was used as the radioactive precursor (see section 2.5.1).

\section{RESULTS}

\subsection{Incorporation of labelled acetate into fatty acids by chloroplast enzymes}

Barley chloroplasts isolated and processed in the glycerol medium at $\mathrm{pH} 9.0$ yield a highly active fatty acid synthesizing stroma fraction. The cofactors necessary for fatty acid synthesis by this stroma fraction when using $(1-14 \mathrm{C})$ acetate as a precursor are shown in Table $\mathrm{I}$. We observed an absolute requirement for ATP and $\mathrm{COA}$, a partial requirement for $\mathrm{ACP}$ and NADPH but no requirement for NADH and bicarbonate. These results indicate the presence of an endogenous pool of cofactors in the stroma fraction.

\section{Table II}

Effect of cold malonyl-CoA on the incorporation of (1-14C)-acetate into fatty acids using the S-300 fasa).

\begin{tabular}{ccc}
\hline $\begin{array}{c}\text { Malonyl-CoA } \\
\text { (nmol) }\end{array}$ & \multicolumn{2}{c}{ Total incorporated b) } \\
(pmol) & (cpm) \\
\hline 0 & 0.3 & 210 \\
12 & 58.9 & 37,120 \\
120 & 83.7 & 52,790 \\
\hline
\end{tabular}

a) The fatty acid synthetase isolated from the stroma of barley chloroplasts has been partially purified by gel filtration on Sephacryl S-300, see section 2.4.1.

b) (1-14C)-acetate was used as the labelled substrate in the fas assay as described in section 2.5.1, except that cold malonyl-CoA was added as indicated. 
Further purification of stroma proteins was done by ammonium sulphate precipitation followed by Sephacryl S-300 gel filtration of the 40 $70 \%\left(\mathrm{NH}_{4}\right)_{2} \mathrm{SO}_{4}$ precipitate. The preparation assayed before and after the gel filtration step were similar in their ability to incorporate $\left(2-{ }^{14} \mathrm{C}\right)$-malonyl-CoA or $\left(1-{ }^{14} \mathrm{C}\right)$-acetyl-CoA into fatty acids, but the latter ( $\mathrm{S}-300$ fas) could no longer synthesize labelled fatty acids from $\left(1-1^{4} \mathrm{C}\right)$-acetate. This may be explained as follows: Acetate is known to be converted to acetylCoA by acetyl-CoA synthetase in the presence of ATP, $\mathrm{Mg}^{++}$and $\mathrm{CoA}$ (32), while malonyl-CoA is formed from acetyl-CoA carboxylase in the presence of $\mathrm{ATP}, \mathrm{CO}_{2}, \mathrm{Mn}^{++}$and $\mathrm{Mg}^{++}(38$, 49). To incorporate $\left(1 .{ }^{4} \mathrm{C}\right)$-acetate into fatty acids, the chloroplast localized acetyl-CoA synthetase, acetyl-CoA carboxylase and fas activities must be present simultanously. Gel filtration on Sephacryl S-300 can potentially separate either the acetyl-CoA synthetase and/or the acetyl$\mathrm{CoA}$ carboxylase from the S-300 fas. These possibilities have been discriminated among by incubating S-300 fas with $\left(1-1^{4} \mathrm{C}\right)$-acetate in the presence and absence of cold malonyl-CoA. The data presented in Table II show that $\left(1-{ }^{14} \mathrm{C}\right)$ acetate is incorporated into fatty acids by $\mathrm{S}-300$ fas only when cold malonyl-CoA is supplied. The S-300 fas preparation, in other words can activate acetate to acetyl-CoA, but it can not carboxylate the latter to form malonyl-CoA. Thus acetyl-CoA synthetase activity is still present in the S-300 fas whereas acetyl-CoA carboxylase activity is absent.

\subsection{Partial purification of the chloroplast stroma fas}

A summary of the purification of the soluble fas isolated from barley chloroplasts is given in Table III. The $99 \%$ of the fas activity which was precipitated by $40-70 \%\left(\mathrm{NH}_{4}\right)_{2} \mathrm{SO}_{4}$ was totally dependent upon addition of exogenous ACP. In accord with these results, the ACP dependent fases from potato tubers (23), avocado mesocarp plastids (52) and Euglena gracilis (10) were precipitated at $40-65,35-65$ and $35-70 \%$ $\left(\mathrm{NH}_{4}\right)_{2} \mathrm{SO}_{4}$ saturations, respectively. The multifunctional, $\mathrm{ACP}$ independent fas from $\mathrm{E}$. gracilis (10), by contrast, was precipitated preferentially by $0-25 \%\left(\mathrm{NH}_{4}\right)_{2} \mathrm{SO}_{4}$ saturation. The total units of fas activity increased substantially upon $\left(\mathrm{NH}_{4}\right)_{2} \mathrm{SO}_{4}$ precipitation. Presumably, this is due to removal of inhibitors or substrate scavenging substances present in the stroma fraction. When the $40-70 \% \quad\left(\mathrm{NH}_{4}\right)_{2} \mathrm{SO}_{4}$ precipitated stroma preparation was fractionated by the S-300 column (Figure 1), the protein separated into three major peaks henceforth referred to as peaks $\mathrm{A}, \mathrm{B}$, and $\mathrm{C}$ in accord with previous terminology (29). The light green color of peak A suggests the presence of chloroplast membrane fragments, while peak B is known to contain ribulose-bisphosphate carboxylase and peak $\mathrm{C}$ to contain glutamate 1 -semialdehyde aminotransferase activity (29). Fas activity eluted symmetrically in peak C (Figure 1), and was found to be purified five-fold compared to the initially isolated stroma fas (Table III).

\subsection{Separation of single component activities of the fas by gel filtration}

\subsubsection{Enzyme activities}

In addition to assaying for fas activity, aliquots from the fractions of the Sephacryl S-300 column were tested for the following enzyme activities; acetyl-CoA:ACP transacylase (Figure 2), malonyl-CoA:ACP transacylase (Figure 2), $\beta$-ketoacyl-ACP synthetase (Figure 3 ) and $\beta$-ketoacyl-ACP reductase (Figure 4). These four

\section{Table III}

Partial purification of the fas from the stroma of barley chloroplasts by ammonium sulphate fractionation and gel filtration chromatography.

\begin{tabular}{lcc}
\hline & (units $\left.\cdot \mathrm{mg}^{-1}\right)$ & Total units \\
\hline Stroma & 1.8 & 2557 \\
$\left(\mathrm{NH}_{4}\right)_{2} \mathrm{SO}_{4}$ & & \\
$0-40 \%$ & 0.4 & 52 \\
$40-70 \%$ & 4.4 & 3751 \\
$70-100 \%$ & 0.0 & 0 \\
S-300 & 11.5 & 1797 \\
\hline
\end{tabular}

a) (2-14C)-malonyl-CoA was used as the labelled substrate for the fatty acid synthetase as detailed in section 2.5.1. Protein was determined by the method of BraDFORD (6). One unit of enzyme is defined as the amount catalyzing the incorporation of $1 \mathrm{nmol}$ of malonyl-CoA into fatty acids $\cdot 15$ $\min ^{-1}$. 


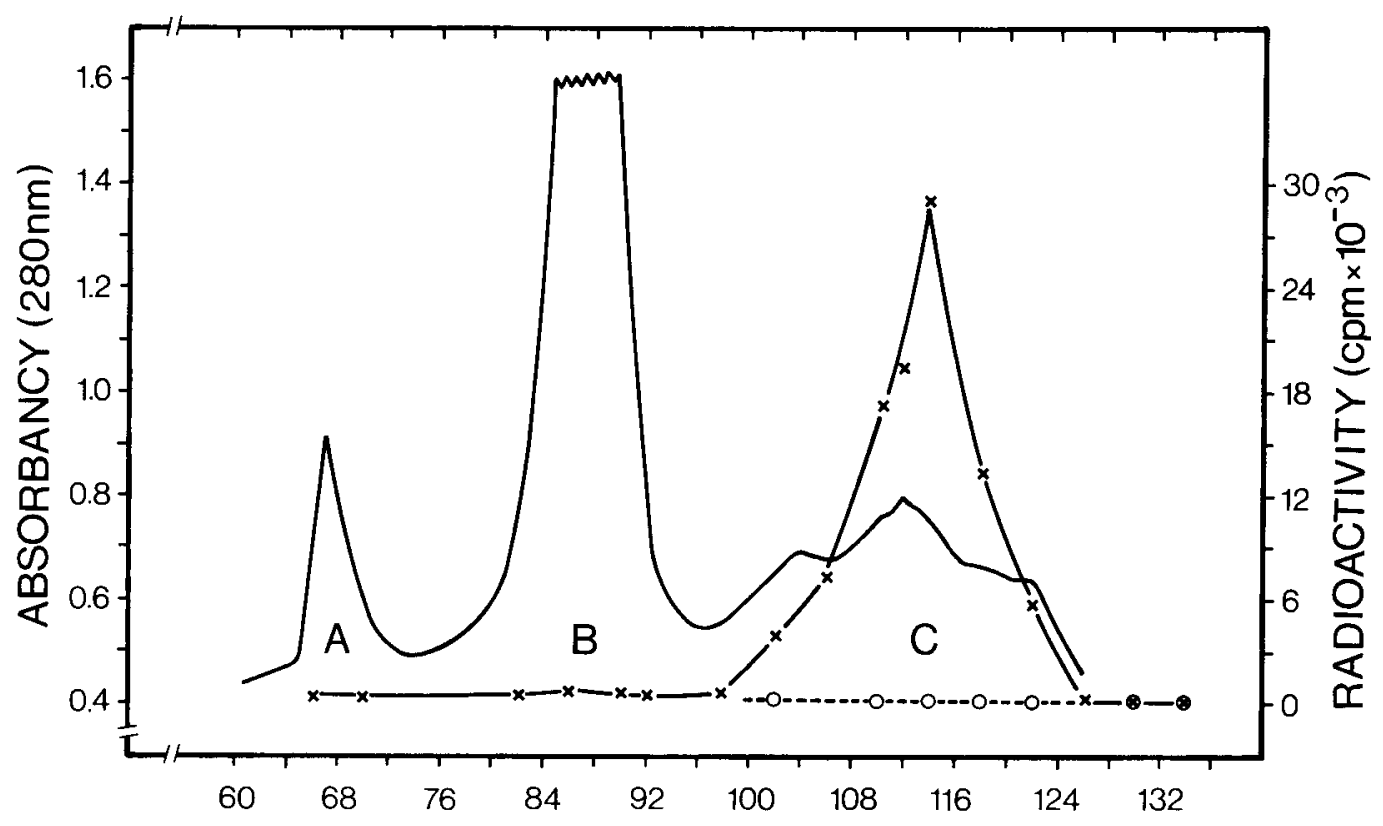

FRACTION NUMBER

Figure 1. Sephacryl S-300 gel filtration of 40-70\% ammonium sulphate precipitated chloroplast stroma proteins.

The precipitated proteins were dissolved in $10 \mathrm{ml}$ suspension medium $(0.1 \mathrm{M}$-Tricine at $\mathrm{pH} 9.0,0.3 \mathrm{M}$ glycerol, 2 mM-DTT) when loaded onto a $5 \times 91 \mathrm{~cm}$ Sephacryl S-300 column. Proteins were eluted with the same medium. The eluate was scanned at $280 \mathrm{~nm}$ for protein (solid line) and $9.5 \mathrm{ml}$ fractions collected. Fas activity was determined in the presence $(\mathrm{x}---\mathrm{x})$ or absence $(\mathrm{O}---\mathrm{O})$ of exogenous ACP using malonyl-CoA as the labelled substrate (see section 2.5.1). $1 \mathrm{nmol}=1939 \mathrm{cpm}$.

activities were localized almost exclusively in the $\mathrm{C}$ peak. This was expected as fas activity is located there (Figure 1). The order of elution of the activities was $\beta$-ketoacyl-ACP reductase, $\beta$ ketoacyl-ACP synthetase, fas, acetyl-CoA:ACP transacylase and malonyl-CoA:ACP transacylase. A similar elution profile for the two latter enzymes in E.coli have been shown by ALBERTs et al. (1). An almost complete separation of the $\beta$-ketoacyl-ACP reductase and the $\beta$-ketoacyl$\mathrm{ACP}$ synthetase was obtained by lowering the flowrate and increasing the effective column length using recycling chromatography as summarized in the legend to Figure 5.

\subsubsection{Molecular weight estimations}

The Sephacryl S-300 column was calibrated with marker proteins and the approximate molecular weights obtained for the $\beta$-ketoacyl$\mathrm{ACP}$ reductase, and $\beta$-ketoacyl-ACP synthetase, fas, acetyl-CoA:ACP transacylase and malonylCoA:ACP transacylase equal $125,92,87,82$ and 41 kilodalton $(\mathrm{kD})$, respectively (Figure 6). These numbers represent average values obtained from several runs, in that the elution volume determined for a single component could differ slightly from run to run, whereas the actual elution order of the activities always remained the same. The observed molecular weights for the total and the partial fas activities leads to the conclusion that the measurable fas activity recovered from the column arises from the overlapping of the individual component activities. Thus, exclusive of ACP, the barley chloroplast fas consists of at least four separable 


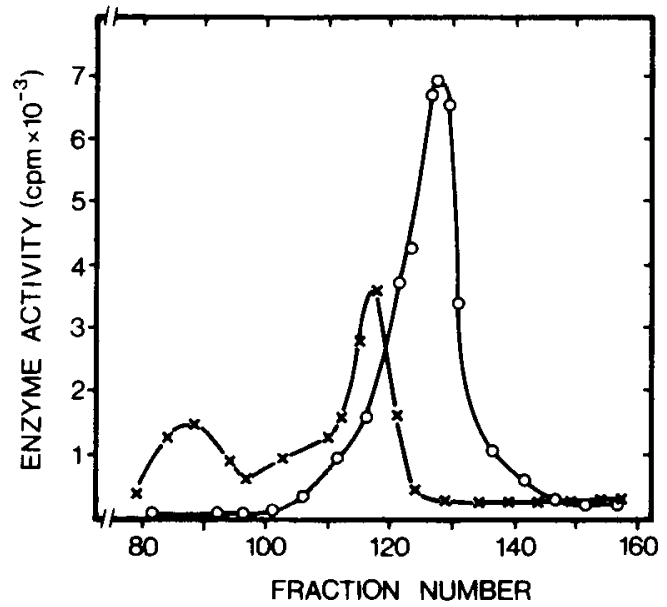

enzymes. In support of the molecular weight estimate given for the malonyl-CoA:ACP trans-
Figure 2. Elution profiles of acetyl-CoA:ACP transacylase $(x---x)$ and malonyl-CoA:ACP transacylase (O--O) activities which have been partially separated by the S-300 column used in Figure 1.

Aliquots $(200$ and $10 \mu \mathrm{l})$ of the fractions were analyzed for the two enzyme activities which are expressed as $\mathrm{cpm}$ transferred from $(1-14 \mathrm{C})$-acetyl$\mathrm{CoA}(1 \mathrm{nmol}=10960 \mathrm{cpm})$ or $(2-14 \mathrm{C}) \cdot$ malonyl$\mathrm{CoA}(1 \mathrm{nmol}=13235 \mathrm{cpm})$ to $\mathrm{ACP}$ respectively $($ see section 2.5.2).

acylase, one of us (P. B. Høu) has analyzed a protein fraction containing this enzyme by SDS polyacrylamide gel electrophoresis. Only two closely positioned bands stained with Coomassie blue in a region corresponding to a molecular weight very similar to that obtained upon gel filtration. Our molecular weight estimations for

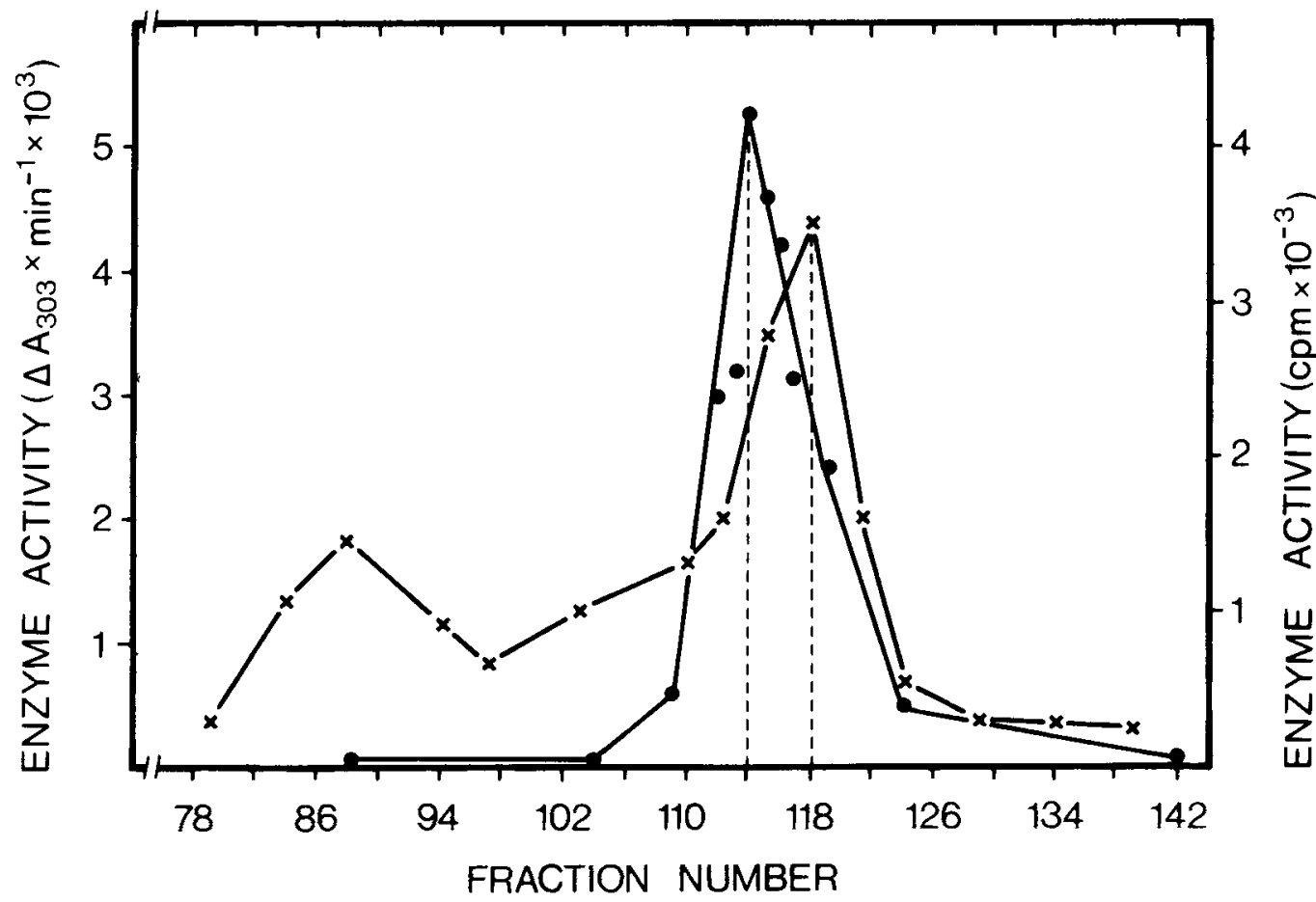

Figure 3. Elution profiles of acetyl-CoA:ACP transacylase ( $x---x)$ and $\beta$-ketoacyl-ACP synthetase (--activities which have been partially separated by the S-300 column used in Figure 1.

The $\beta$-ketoacyl-ACP synthetase activity is given as the change in absorption at $303 \mathrm{~nm} \cdot \mathrm{min}^{-1} \times 10^{-3} .600 \mu \mathrm{l}$ was used from each $9.5 \mathrm{ml}$ fraction (see section 2.5.3). Acetyl-CoA:ACP transacylase activity is expressed as in Figure 2. 

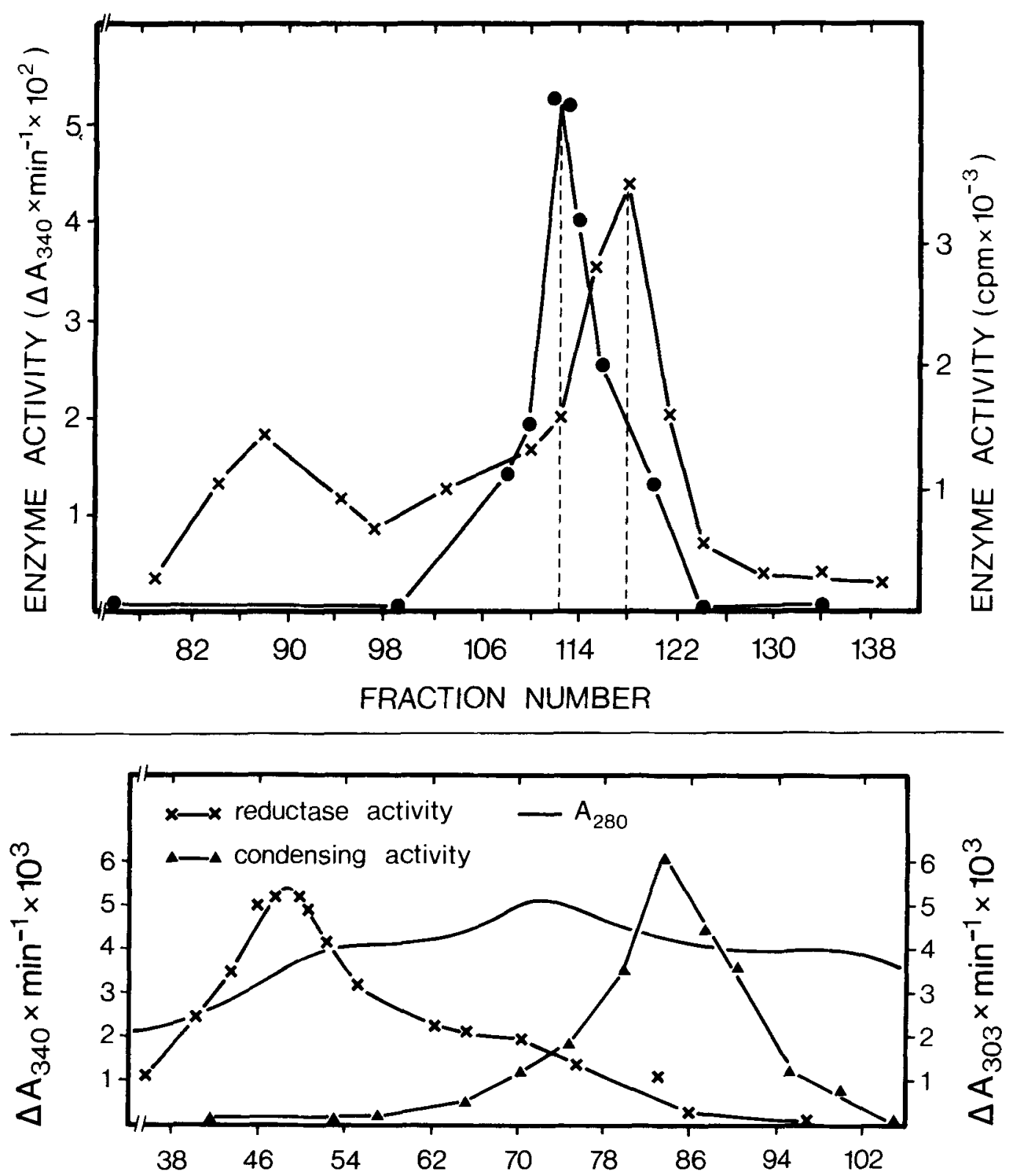

\section{FRACTION NUMBER}

Figure 5. Recycling gel filtration chromatography of the 40-70\% ammonium sulphate fractionated chloroplast stroma proteins separates the $\beta$-ketoacyl-ACP synthetase and $\beta$-ketoacyl-ACP reductase activities.

The precipitated proteins were dissolved in $10 \mathrm{ml}$ suspension medium and loaded onto a $5 \times 44 \mathrm{~cm}$ Sephacryl S-300 column. The C peak therefrom was loaded continuously onto a second $5 \times 91 \mathrm{~cm}$ Sephacryl S-300 column. Both columns were equilibrated and eluted with suspension medium at a flow rate of $30 \mathrm{ml} \cdot \mathrm{hr}^{-1}$. Inlet and outlet of the latter column were connected through a peristaltic pump and the protein recycled before the $C$ peak was collected. Aliquots of the collected $9.5 \mathrm{ml}$ fractions were assayed for the indicated enzyme activities as detailed in Figures 3 and 4 . $\beta$-ketoacyl-ACP synthetase activity is expressed as in Figure 3. $\beta$-ketoacyl-ACP reductase activity is expressed as the change in absorption at $340 \mathrm{~nm} \cdot \mathrm{min}^{-1} \times 10^{-3} .600 \mu \mathrm{l}$ was used from each $9.5 \mathrm{ml}$ fraction. 
Figure 4. Elution profiles of acetyl-CoA:ACP transacylase $(\mathrm{x}---\mathrm{x})$ and $\beta$-ketoacyl-ACP reductase (--activities which have been partially separated by the S-300 column used in Figure 1.

The enzyme activity for the $\beta$-ketoacyl-ACP reductase is given as the change in absorption at $340 \mathrm{~nm} \cdot \mathrm{min}^{-1}$ $\times 10^{-2} .300 \mu \mathrm{l}$ was used from each fraction (see section 2.5.4). Acetyl-CoA:ACP transacylase activity is expressed as in Figure 2.

this enzyme are thus quite similar to the $36 \mathrm{kD}$ reported for the E.coli enzyme (42). Likewise, our estimate for the $\beta$-ketoacyl-ACP synthetase is close to the values $(80$ and $85 \mathrm{kD})$ reported for the two $\beta$-ketoacyl-ACP synthetases in E.coli (15). Molecular weight estimates for the same enzymes from E. gracilis (21), however are markedly greater $(160 \mathrm{kD}$ for the malonylCoA:ACP transacylase and $118 \mathrm{kD}$ for $\beta$ ketoacyl:ACP synthetase). This difference may result from physical interaction among some or all of the component activities in Euglena gracilis.

\subsection{3. $A C P$}

ACP a fifth component of barley chloroplast fas has also been studied. The ACP was separated from the other four component activities by $\left(\mathrm{NH}_{4}\right)_{2} \mathrm{SO}_{4}$ precipitation. The supernatant resulting from $70 \%$ saturation of the chloroplast stroma proteins was heat treated, acid precipitated and the ACP was purified by ion exchange chromatography (Figure 7). When the malonylCoA:ACP transacylase based assay was used to locate ACP in the eluate, two closely positioned peaks were obtained. An elution profile exactly parallel to the former was obtained when the

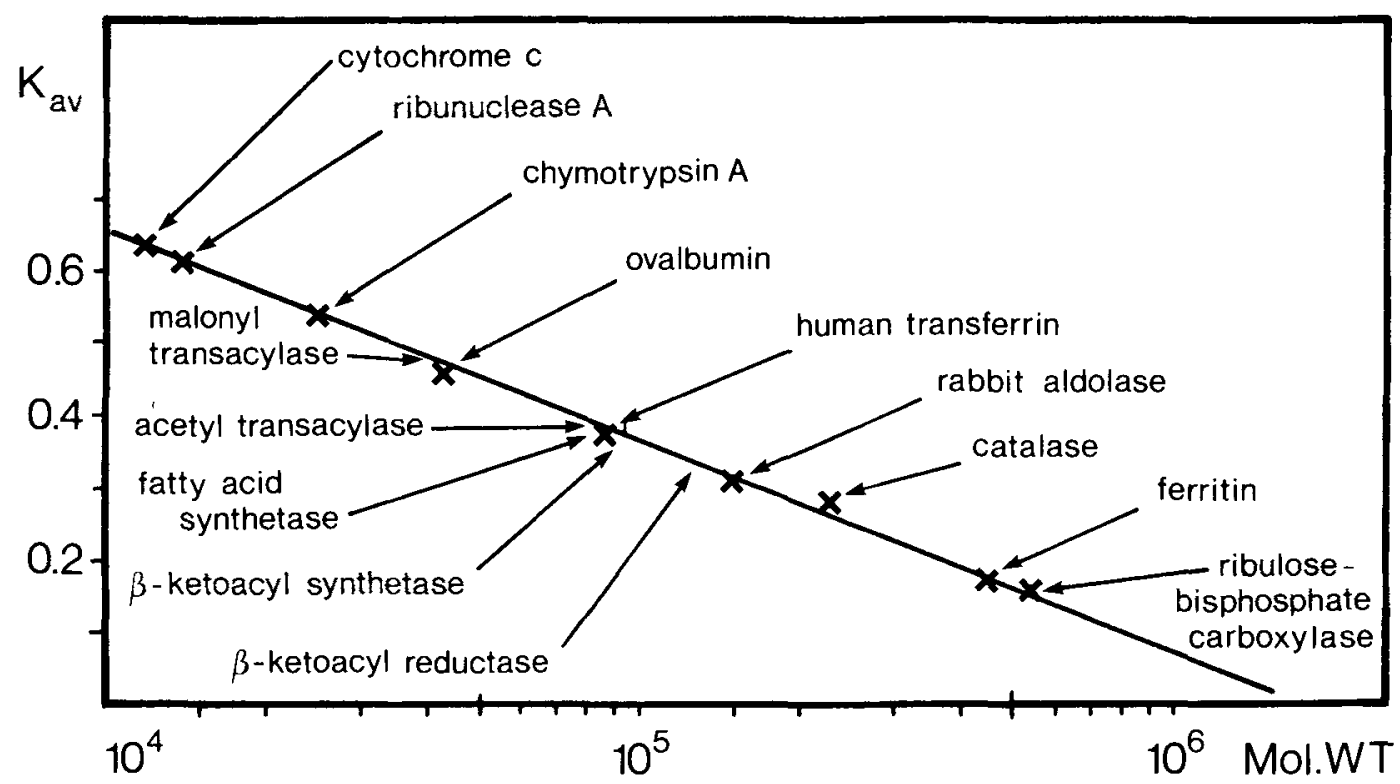

Figure 6. Calibration of the $5 \times 91 \mathrm{~cm}$ Sephacryl S-300 column for determination of approximate molecular weights.

One, two or three standard proteins (20-50 mg each) with known molecular weights were dissolved in $10 \mathrm{ml}$ suspension medium and gel filtrated using the same conditions as those for the ammonium precipitated stroma proteins. The elution volume for the individual proteins was determined by continuous scanning at $280 \mathrm{~nm}$. Total volume, $V_{t}$, of the column was $1787 \mathrm{ml}$ and the void volume $V_{0}=640 \mathrm{ml}$. $V_{e}$ is the elution volume of the protein. The data are plotted according to Locasio et al. (33).

$\mathrm{K}_{\mathrm{av}}=\frac{\mathrm{V}_{\mathrm{e}}-\mathrm{V}_{\mathrm{o}}}{\mathrm{V}_{\mathrm{t}}-\mathrm{V}_{\mathrm{o}}}$ 


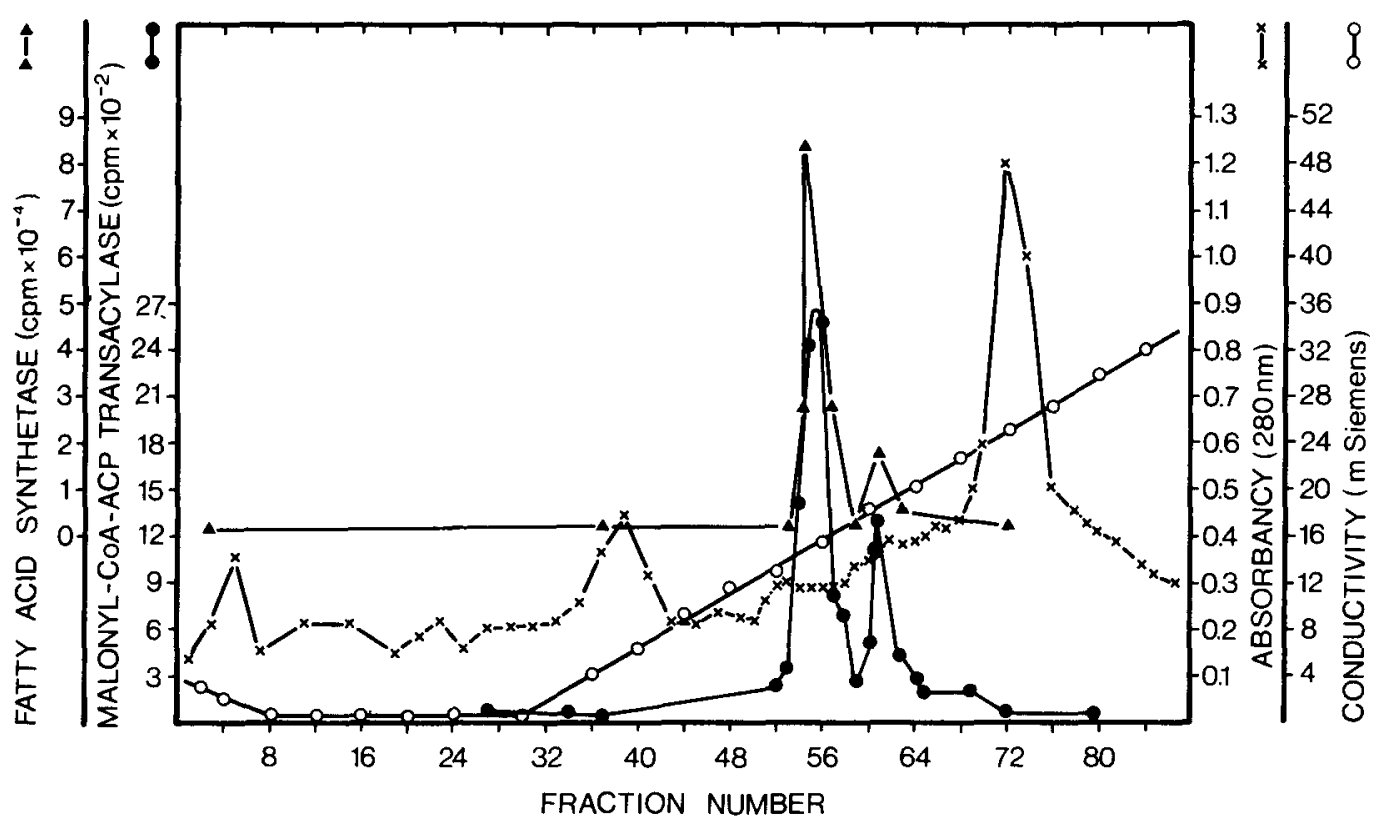

Figure 7. Elution profile of barley ACP from a DEAE Sepharose CL $6 \mathrm{~B}$ ion exchange column.

The presence of barley ACP in the $2.8 \mathrm{ml}$ fractions was determined by measuring ACP dependent $\mathrm{S}-300$ fas $(\triangle--\triangle)$ and malonyl-CoA:ACP tranacylase (-- -1$)$ activities. Fas activity was measured under the standard conditions using (2-14C)-malonyl-CoA, except that only $11.6 \mathrm{nmoles}(167,000 \mathrm{dpm})$ were used (see section 2.5.1). The malonyl-CoA:ACP trasacylase assay was performed as described in the last paragraph of section 2.5.2. Optical density at $280 \mathrm{~nm}(\mathrm{x}---\mathrm{x})$ and conductivity $(\mathrm{O}---\mathrm{O})$ of the fractions were also determined.

fractions were tested for their ability to replace E.coli ACP in fatty acid synthesis. From these results we conclude that $\mathrm{ACP}$ is present in the stroma of barley chloroplasts. Fatty acid synthesis by S-300 fas was absolutely dependent upon the presence of ACP and was found to increase

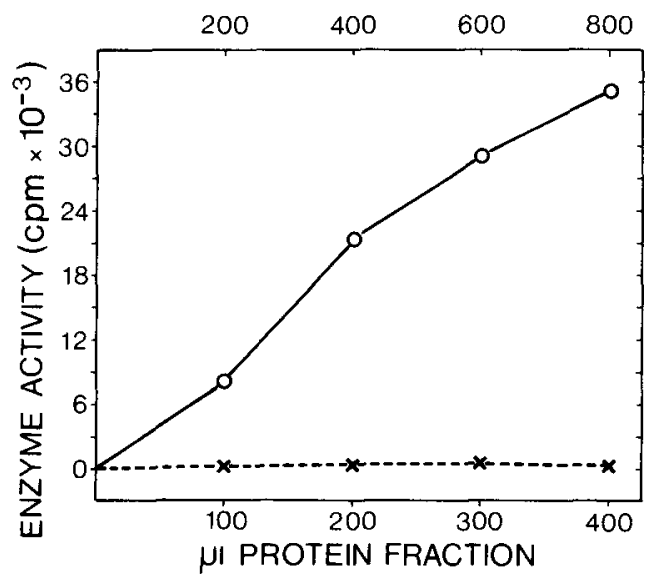

linearly with the amount of barley ACP added. An analogous profile of E.coli $\mathrm{ACP}$ after passage through an ion exchange column has been reported previously (17). The reason for this double headed curve for the barley ACP is not clear, but if the heat treatment is omitted and the 2-propanol extractable proteins chromatographed on the same column the ACP activity elutes as a single symmetrical peak.

Figure 8. Reconstruction of S-300 fas after separation of the enzyme activity into a bound and a non-bound protein fraction by affinity chromatography on $\mathrm{Ma}$ trex Gel Blue B.

$\mathrm{x}---\mathrm{x}$ fas activity in either the bound or nonbound protein fraction. $O_{---} O^{\prime}$ fas activity when equal volumes of bound and non-bound protein fractions were combined; total volume shown on top horizontal axis. $100 \mu \mathrm{l}$ bound $=90 \mu \mathrm{g}$ protein and $100 \mu \mathrm{l}$ non-bound $=56 \mu \mathrm{g}$ protein. Fas activity is expressed as cpm incorporated into fatty acids from $\left(2-1^{4} \mathrm{C}\right)$-malonyl-CoA. $1 \mathrm{nmol}=1939 \mathrm{cpm}$. 


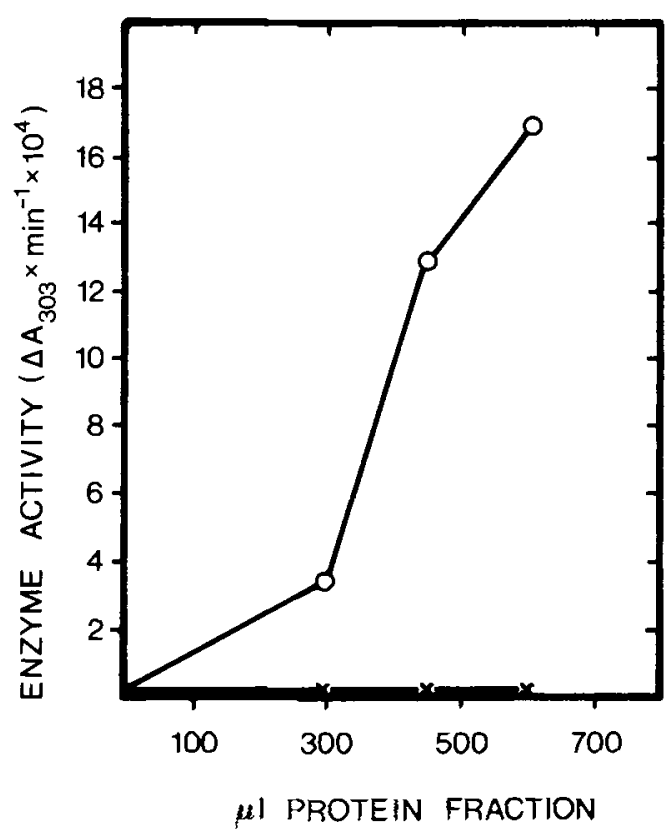

Figure 9. $\beta$-ketoacyl-ACP synthetase activity in the bound $(x---x)$ and non-bound $(\mathrm{O}---\mathrm{O})$ protein fractions from the Mātrex Gel Blue B column (see Figure 8).

Enzyme activity is expressed as change in absorbancy at $303 \mathrm{~nm} \cdot \mathrm{min}^{-1} \times 10^{-4}$.

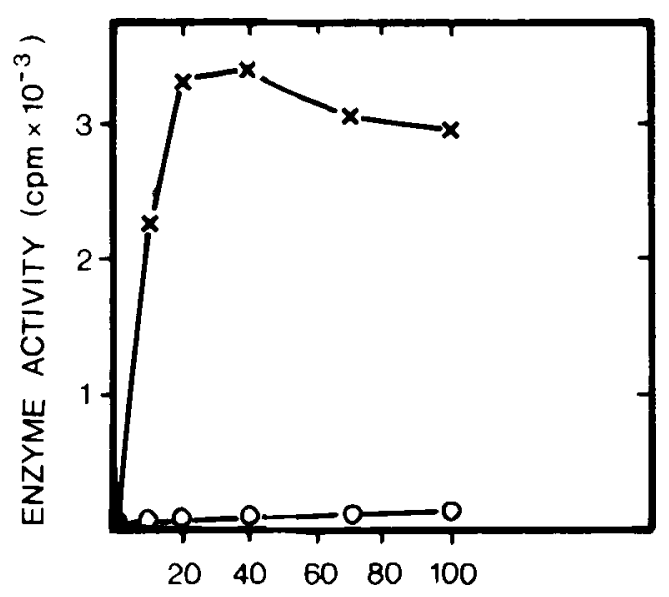

\section{aI PROTEIN FRACTION}

Figure 10. Malonyl-CoA:ACP transacylase activity in bound $(x---x)$ and non-bound $(O---O)$ protein fractions from the Matrex Gel Blue B column (see Figure 8).

Enzyme activity is expressed as cpm transferred from $(2.14 \mathrm{C})$.malonyl-CoA to $\mathrm{ACP} .1 \mathrm{nmol}=$ $13235 \mathrm{cpm}$.

\subsection{Reconstitution of fas}

Our results obtained with Sephacryl S-300 gel filtration indicated that barley chloroplast fas is composed of discrete unifunctional enzymes. We have explored this aspect of the fas structure with the aid of dyeligand column chromatography. The S-300 fas was fractionated using a Mātrex Gel Blue B column into non-bound and bound proteins. Figure 8 illustrates the enzyme response curves obtained when increasing concentrations of non-bound protein, bound protein and the two in combination were assayed for fas activity. Clearly neither of the fractions catalyzes fatty acid synthesis alone. Combination of the two specified protein fractions actually resulted in a fas with increased specific activity compared to that of the S-300 fas. for which a number of explanations could be suggested. We conclude that at least two component activities have been separated completely from each other, one being localized in the non-bound fraction, the other in the bound fraction. The two protein fractions were then assayed for the presence of individual enzyme activities. Initially the $\beta$-ketoacyl-ACP synthetase was found exclusively in the nonbound fraction and the malonyl-COA:ACP transacylase exclusively in the latter as shown in Figures 9 and 10, respectively. The non-bound fraction was unable to catalyze fatty acid synthesis when supplied with E.coli malonylCoA:ACP transacylase or chemically prepared malonyl-ACP, which indicated that a second component activity must be present in the bound fraction. This has been identified as the $\beta$ ketoacyl-ACP reductase.

The only previous study supporting the view that a plant fas may be made up of several components excluding ACP was carried out using a fatty acid synthesizing system isolated from lettuce chloroplasts (7). The fas was fractionated by isoelectric precipitation at $\mathrm{pH}$ 5.0. The soluble fraction was devoid of fas activity, whereas the precipitated fraction gave a measurable activity. Combination of the two fractions, however, stimulated fas activity sixfold on a protein basis.

\subsection{General porperties of $S-300$ fas}

The activity of S-300 fas increased linearly under the standard fas assay conditions with 


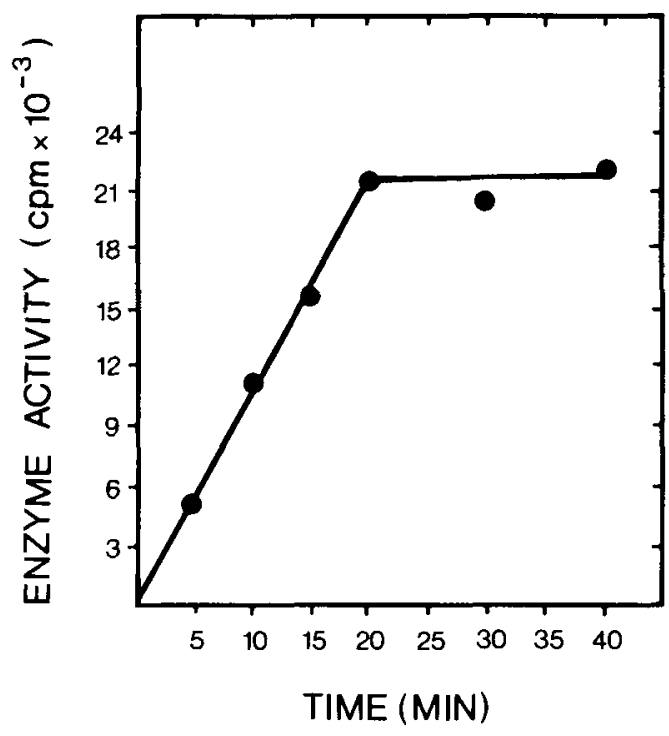

Figure 11. Time course of fatty acid synthesis using $880 \mu \mathrm{g}$ of S-300 fas under standard assay conditions with $(1.14 \mathrm{C}$ )-acetyl-CoA (see section 2.5 .1$) .1 \mathrm{nmol}$ $=10960 \mathrm{cpm}$.

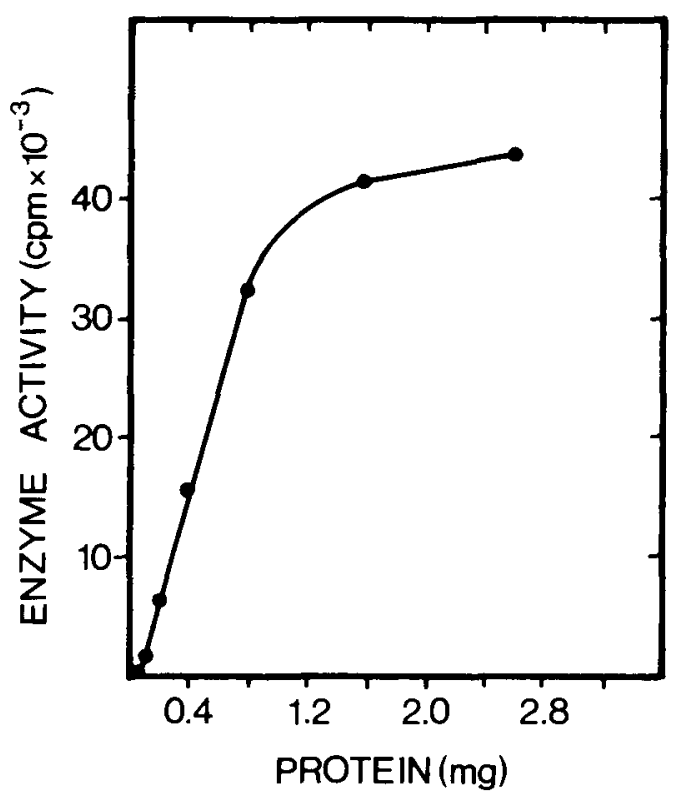

Figure 12. Fatty acid synthesis as a function of S-300 fas protein concentration under standard assay conditions using $(2-14 \mathrm{C}$ )-malonyl-CoA (see section 2.5.1). $1 \mathrm{nmol}=1939 \mathrm{cpm}$. respect to time (Figure 11) and protein at concentrations higher than $100 \mu \mathrm{g}$ (Figure 12). In the stroma preparation, however, $500 \mu \mathrm{g}$ proteins were required to obtain measurable activity.

Interestingly, the $\mathrm{pH}$ optimum for the S-300 fas was approximately 8.3 in the Tricine medium (Figure 13). This rather alkaline $\mathrm{pH}$ optimum is also characteristic for another barley chloroplast enzyme, namely glutamate-1-semialdehyde aminotransferase (28). Since the thioester bonds in malonyl-CoA and acetyl-CoA are quite labile, the $\mathrm{pH}$ of the standard fas assay incubation medium (8.7) might be considered too high. To investigate this question we determined the rate of thioester hydrolysis by spectrophotometric DTNB measurements (13). Fifteen min incubations with DTNB and suspension medium gave identical results in the presence and absence of acetyl- or malonyl-CoA indicating that no measurable hydrolysis of the CoA-derivatives occurred during the standard assay.

\subsubsection{Cofactor requirements}

We could characterize the S-300 fas since $\left(\mathrm{NH}_{4}\right)_{2} \mathrm{SO}_{4}$ precipitation and S-300 gelfiltration

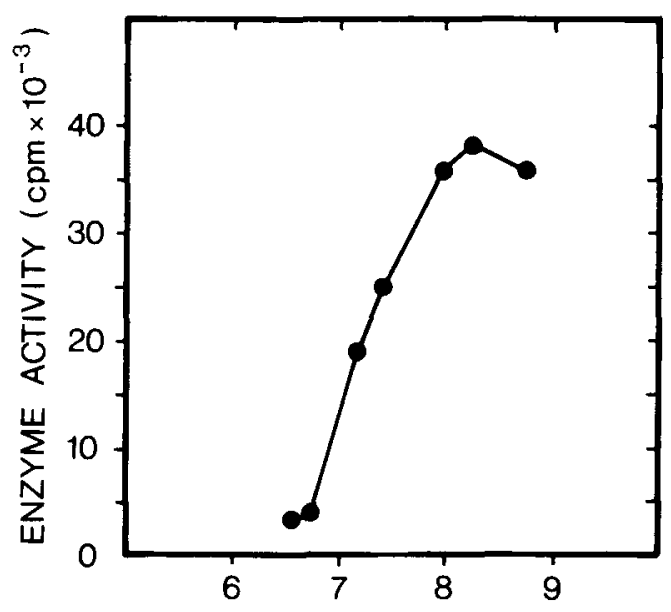

Figure 13. Effect of incubation $\mathrm{pH}$ on $\mathrm{S}-300$ fas (1 $\mathrm{mg})$ activity using $(2-1+\mathrm{C})$ malonyl-CoA as labelled substrate (see section 2.5.1).

The $\mathrm{pH}$ values indicated are those of the reaction medium during incubation as measured by a $\mathrm{pH}$ meter. All reactions were performed in Tricine buffer. I $\mathrm{nmol}=1939 \mathrm{cpm}$. 


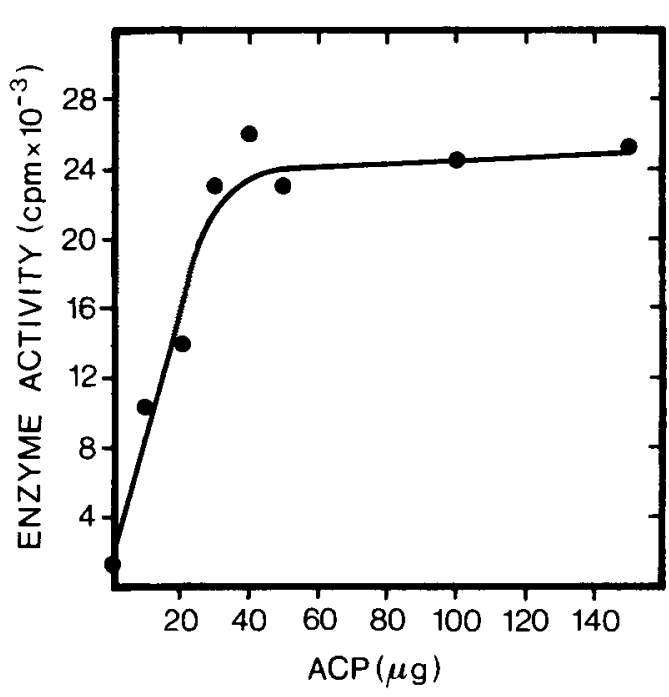

Figure 14. S-300 fas requires ACP, in this case from E. coli, for fatty acid synthesis.

Malonyl-CoA was used as labelled substrate in the fas standard assay (see section 2.5 .1 ). $1 \mathrm{nmol}=1939$ cpm.

completely removes low molecular weight cofactors from the initially isolated fas containing stroma preparation. The S-300 fas showed an absolute requirement for ACP (Figure 14),

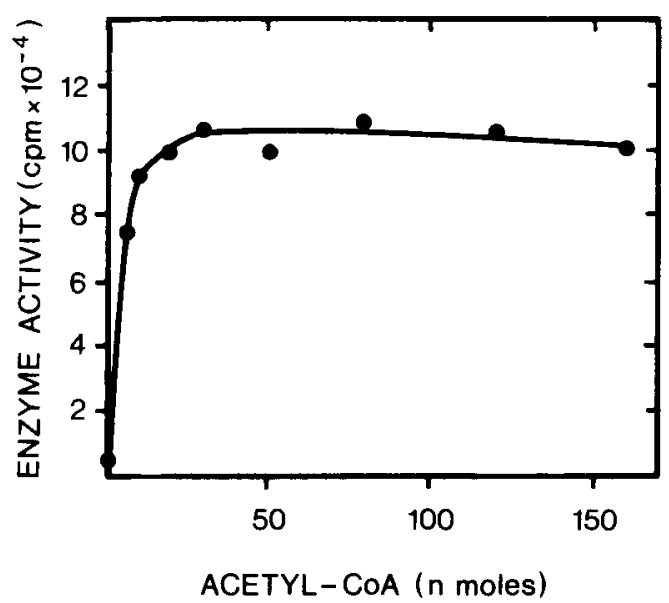

Figure 15. Acetyl-CoA is required by the $\mathrm{S}-300$ fas for fatty acid synthesis.

Fas activity was measured under the standard assay conditions using malonyl-CoA except that only $11.6 \mathrm{nmoles}(167.000 \mathrm{dpm})$ was added (see section 2.5.1). $1 \mathrm{nmol}=13532 \mathrm{cpm}$

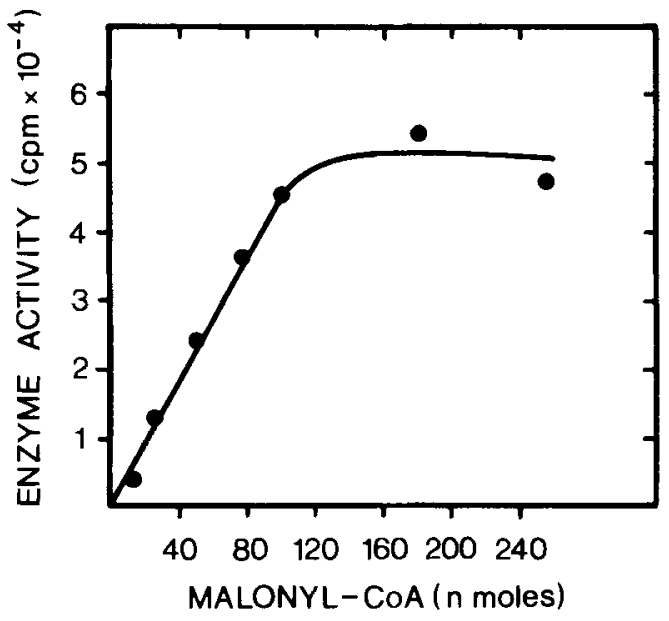

Figure 16. Malonyl-CoA is required by the $\mathrm{S}-300$ fas for fatty acid synthesis.

Fas activity was measured under the standard assay conditions using $(1-14 \mathrm{C}$ )-acetyl-CoA (see section 2.5 .1$) .1 \mathrm{nmol}=10940 \mathrm{cpm}$.

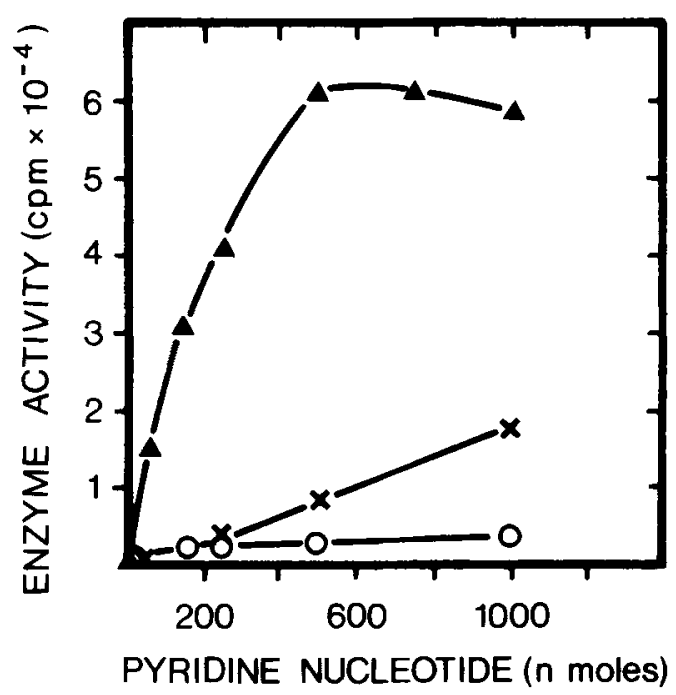

Figure 17. Pyridine nucleotide requirements of the S-300 fas.

Standard conditions using both $(2-14 \mathrm{C})$-malonyl$\operatorname{CoA}(64$ nmoles) and (1-14C)-acetyl-CoA (11.6 nmoles were employed) to measure fas activity (see section 2.5.l). In experiments where only one nucleotide was added the amount of that nucleotide is specified; NADPH $(-x-x-)$, NADH $(-O-O-)$. In experiments where both NADPH and NADH $(\Delta-\Delta)$ were used, the amounts of each nucleotide were exactly one half of the total values indicated on the horizontal axis. 
acetyl-CoA (Figure 15), malonyl-CoA (Figure 16) as well as NADPH and NADH in combination (Figure 17). The S-300 fas was saturated with E.coli ACP at a concentration of 35-45 $\mu \mathrm{g}$. $0.8 \mathrm{ml}^{-1}$. This is in good agreement with results obtained for the ACP dependent fas in E. gracilis (14) and potato tuber (23). The absolute requirement for acetyl-CoA shows that malonyl-CoA decarboxylase activity is absent in the partially purified S-300 fas. Furthermore, the chemically synthesized $\left(2-1^{4} \mathrm{C}\right)$-malonyl-CoA must be free of contaminating $\left(2-1{ }^{4} \mathrm{C}\right)$-acetyl-CoA, in accord with the HPLC analysis.

\subsubsection{Substitution of acetyl-and malonyl- CoA:ACP transacylase products for acetyl-and malonyl-COA}

The $\left(1-{ }^{14} \mathrm{C}\right)$-acetyl-CoA and $\left(2-{ }^{4} \mathrm{C}\right)$-malonylCoA substrates for $\mathrm{S}-300$ fas can be replaced by the labelled acid precipitable products formed during the acetyl- and malonyl-CoA:ACP transacylase assay reaction, respectively (see section 2.5.2.). The results when these substrates individually were the only source of label in fas assays are shown in Table IV. When either labelled substrate was used, the distribution of labelled fatty acyl chains synthesized was identical to that obtained when labelled acetyl- and malonyl-CoA are used (results not shown). Due to the excess amount used in the transacylase

\section{Table IV}

Incorporation of transacylase reaction products into fatty acidsa).

\begin{tabular}{ccc}
\hline Experiment & $\begin{array}{c}\text { Acid precipitable } \\
\text { reaction product } \\
\text { (cpm) }\end{array}$ & $\begin{array}{c}\text { Fatty acids } \\
\text { synthesized } \\
\text { (cpm) }\end{array}$ \\
\hline 1 & 42,404 & 8,390 \\
2 & 61,200 & 14,115 \\
\hline
\end{tabular}

a) Synthesis of fatty acids was measured as described in section 2.5 .1 with the following modifications. In the first experiment $75 \mathrm{nmol}$ of cold malonyl$\mathrm{CoA}$ was used with the ${ }^{14} \mathrm{C}$-labelled product from the acetyl-CoA:ACP-transacylase reaction, while in the second experiment $90 \mathrm{nmol}$ of acetyl-CoA was used with the ${ }^{14} \mathrm{C}$-labelled product from the malonyl-CoA:ACP-transacylase reaction. incubation mixture, addition of $\mathrm{ACP}$ was not necessary in these fas assays.

Using the spectrophotometric fas assay chemically synthesized acetyl-ACP and malonyl-ACP were shown to substitute for acetyl-CoA and malonyl-CoA. ACP was not required when both CoA derivatives were simultaneously substituted for by their ACP analogues. The products of the acetyl- and malonyl-CoA:ACP transacylase reactions therefore appear to be acetyl- and malonylACP, respectively. Further support for this contention was obtained when another large scale malonyl-CoA:ACP transacylase reaction mixture was applied directly to a Sephadex G-75 gel filtration column (see section 2.4.1.). Two completely separated radioactive peaks were obtained, one eluting in the protein region as judged by molecular weight markers, while the unreacted $\left(2-{ }^{4} \mathrm{C}\right)$-malonyl-CoA eluted in the salt region. When aliquots of the protein peak were subjected to SDS polyacrylamide gel electrophoresis only one major band occured upon staining with Commassie blue. This band had the same $\mathbf{R}_{f}$ value as E.coli ACP. When the product of the acetyl- and malonyl-CoA:ACP transacylase reactions from E.coli was gel filtrated on Sephadex G-75 a similar elution profile was obtained, and the first radioactive peak shown to be $(2.14 \mathrm{C})$ malonyl-ACP or $\left(1.1^{4} \mathrm{C}\right)$-acetyl-ACP, respectively (49). Finally chemically prepared acetylACP, acetoacetyl-ACP and crotonyl-ACP, which are the first protein bound $\mathrm{C}_{2^{-}}$and $\mathrm{C}_{4-}$ intermediates in E.coli de novo fatty acid synthesis, were found to completely replace acetyl-CoA as the primer in the synthesis of fatty acids from $\left(2-{ }^{4} \mathrm{C}\right)$-malonyl-CoA catalyzed by S-300 fas.

\subsubsection{Pyridine nucleotides}

NADPH can serve as an inefficient electron donor for fatty acid synthesis catalyzed by $\mathrm{S}-300$ fas, whereas NADH cannot do so at the concentrations tested (Figure 17). Optimal activity, however, is obtained when both pyridine nucleotides are present together at a total concentration of 500 nmoles per assay. This synergistic effect of NADH and NADPH in de novo fatty acid synthesis has also been reported for the ACP dependent fases from E.coli (53) and safflower seeds (24) as well as for the ACP 
independent fases from yeast, Mycobacterium smegmatis (54) and E. gracilis (16). It has been suggested $(16,53,54)$ that this stems from different pyridine nucleotide requirements of the two reductive steps in fatty acid synthesis; namely, NADPH and NADH serve as specific reductants for the $\beta$-ketoacyl-ACP reductase and the enoyl-ACP reductase, respectively. In the present studies when assaying S-300 fractions for $\beta$-ketoacyl-ACP reductase activity, identical elution profiles were obtained with acetoacetylACP and acetoacetyl-pantotheine as the thioester component. Reduction of both substrates readily took place with NADPH as electron donor, whereas the enzyme was completely inactive with NADH. Thus, as in E.coli (1) the $\beta$ ketoacyl-ACP reductase of the barley chloroplast lacks specificity toward the acetoacetyl-thioester but exhibits strict specifity toward the reduced pyridine nucleotide. In view of the latter plus the synergistic effect between NADH and NADPH observed with the $S-300$ fas, we predict that the barley chloroplast enoyl-ACP reductase will show a pronounced preference for NADH.

Very interestingly both NADPH and NADH dependent enoyl-ACP reductase activities have been demonstrated in E.coli (53). The former is unstable and inactive at $\mathrm{pH}$ values $>8.0$, while the latter is highly active in the $\mathrm{pH}$ region $6-9$. The synergistic effect of the pyridine nucleotides in fatty acid synthesis was much more pronounced in E.coli at pH 9.0 than at pH 7.0. The S-300 fas has not been tested for synergistic effects at $\mathrm{pH}$ 7.0. The possible existence of two enoyl reductase activities with different $\mathrm{pH}$ optima and pyridine nucleotide requirements, however, could account for the lack of a pronounced NADH requirement found in some plant systems $(40$, 45) when assayed at $\mathrm{pH}$ values lower than 8.7. On the other hand, since the observation that barley fas requires $\mathrm{NADH}$ only became apparent upon purification of the crude stroma fraction, we suggest that the lack of a NADH requirement reported for castor bean (45) and spinach preparations (40) might be due to the presence of endogenous NADH.

\subsection{Product of fas}

A comparison among the fatty acids synthesized by the chloroplast's stroma, ammonium sulphate and S-300 fractions is presented in

\section{Table V}

Per cent distribution of radioactivity in the products of fatty acid synthetase (fas) at various stages during purification.

\begin{tabular}{|c|c|c|c|c|c|c|c|c|}
\hline \multirow[t]{2}{*}{ Fas source and substrate } & \multicolumn{7}{|c|}{$\begin{array}{l}\text { Fas products } \\
\text { (chain lengths) }\end{array}$} & \multirow{2}{*}{$\begin{array}{c}\text { Total cpm } \\
\left(\times 10^{-4}\right)\end{array}$} \\
\hline & 10 & 12 & 14 & 16 & 17 & 18 & 20 & \\
\hline \multicolumn{9}{|l|}{ Stroma } \\
\hline$(1-14 C)$-acetate & 1 & 1 & 2 & 11 & 2 & 77 & 6 & 223 \\
\hline$(1-14 \mathrm{C})$-acetyl-CoA & 3 & 2 & 2 & 19 & - & 74 & - & 4.5 \\
\hline$(2-14 \mathrm{C})$-malonyl-CoA & 2 & 2 & 2 & 15 & - & 79 & - & 4.9 \\
\hline \multicolumn{9}{|l|}{$\left.35-70 \%\left(\mathrm{NH}_{4}\right)_{2} \mathrm{SO}_{4}^{\mathrm{a}}\right)$} \\
\hline$\left(1-1^{4} \mathrm{C}\right)$-acetate & - & - & - & 18 & 2 & 80 & - & 380 \\
\hline \multicolumn{9}{|l|}{ S-300 } \\
\hline$\left(1-1{ }^{4} \mathrm{C}\right)$-acetyl-CoA & - & - & - & 18 & - & 80 & 2 & 3.3 \\
\hline$(2-14 \mathrm{C})$-malonyl-CoA & - & - & 2 & 41 & - & 57 & - & 6.1 \\
\hline$(2-14 \mathrm{C})$-malonyl-CoA & - & - & - & 21 & - & 79 & - & 7.9 \\
\hline
\end{tabular}

a) The stroma proteins were precipitated in this case with $35-70 \%$ ammonium sulphate and desalted before assaying on a Sephadex G-50 column equilibrated in suspension medium.

$-=$ not detectable. 


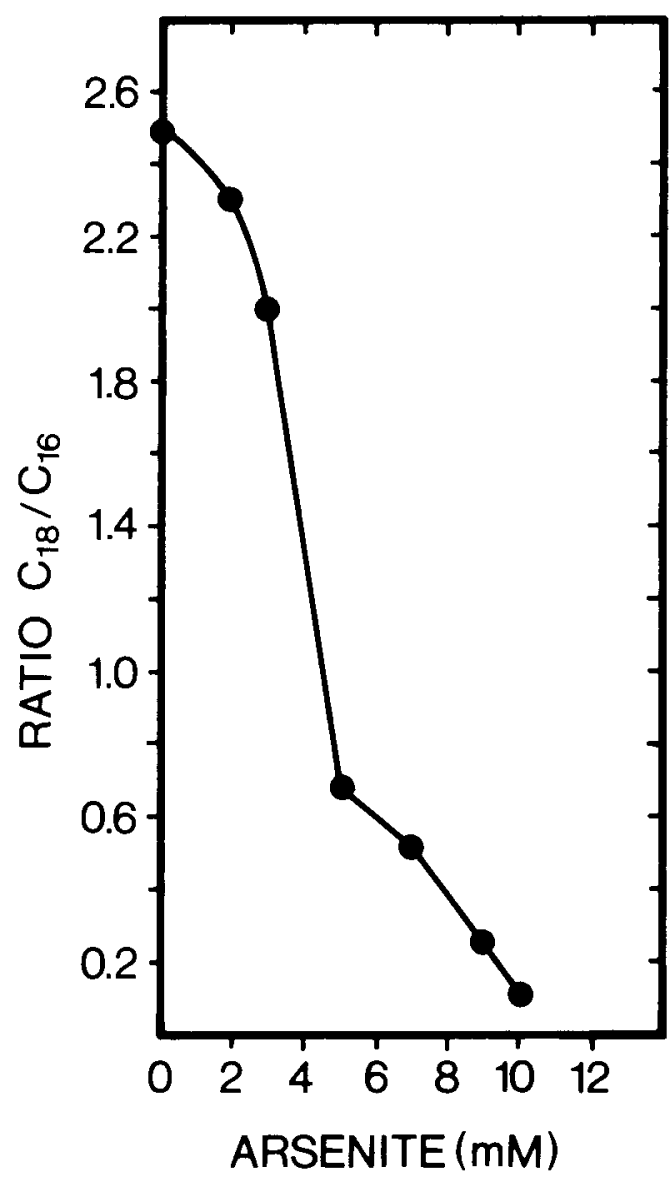

Figure 18. Effect of arsenite on the synthesis of stearic and palmitic acid by S-300 fas.

Malonyl-CoA was employed as labelled substrate under standard assay conditions (see section 2.5.1). Ratios given are based on a minimum of $4,000 \mathrm{cpm}$. Note: incubation medium contained $2.5 \mathrm{~mm}$-DTT.

Table V. Stearic and palmitic acids are the major components and regardless of purification stage constitute more than $86 \%$ of the total radioactivity incorporated under standard assay conditions. This is in marked contrast to intact chloroplasts from barley, where palmitic and oleic acid represent more than $90 \%$ of the fatty acids synthesized, whereas less than $1 \%$ of the label is found in stearic acid (J. D. Mikkeisen, unpublished results). The relative amounts of palmitic and stearic acid synthesized are very reproducible except when $\left(2-1^{4} \mathrm{C}\right)$-malonyl-CoA was used as a precursor with the S-300 fas (Ta- ble V). The reason for this is not clear, but may perhaps be explained as follows: In several plant systems such as potato tuber (23), avocado (19), developing safflower seeds (24) and spinach chloroplasts (40), two independent systems are apparently responsible for the synthesis of palmitic and stearic acid. An arsenite insensitive de novo system forms palmitoyl-ACP (the palmitoyl-ACP synthetase), while an arsenite sensitive elongase produces stearoyl-ACP from palmitoyl-ACP by addition of one $\mathrm{C}_{2}$-unit (24). Indirect evidence for the existence of two such independent enzyme systems in the barley S-300 fas has come from inhibitor studies with arsenite. As shown in Figure 18 the ratio of stearic to palmitic acid synthesized is drastically reduced (from 2.45 to 0.09 ) when the concentration of arsenite is increased from 0 to $10 \mathrm{~mm}$. The total amount of palmitic acid synthesized remained constant up to $8 \mathrm{~mm}$-arsenite. Given that the elongase is more labile than the synthetase in other aspects also might explain the variability in the product pattern obtained with S-300 fas under apparently identical conditions. In support of this is the observation that several plant fases have been reported to loose their ability to synthesize stearic acid upon partial purification $(19,49)$.

\subsection{Factors affecting the distribution of fatty acids synthesized by $S-300$ fas}

Although constant under the standard assay conditions, the pattern of fatty acids synthesized could be greatly influenced by alterations of the substrate concentrations. Figures 19 and 20 show the results obtained when the absolute concentrations of acetyl-CoA and malonyl-CoA were varied. At a low acetyl-CoA level, stearic and palmitic acids are by far the major products, whereas with increasing acetyl-CoA concentrations the pattern changes so that synthesis of the $\mathrm{C}_{14}$ and shorter fatty acids is elevated. Varying the malonyl-CoA concentration had the opposite effect with regard to the proportions of the $C_{16}$ and $C_{18}$ fatty acids. The latter was enhanced with increasing malonyl-CoA concentrations. Although different S-300 fas preparations have been used for the two analyses in Figures 19 and 20 repeated experiments with malonyl-CoA have confirmed the same marked tendency. It is 


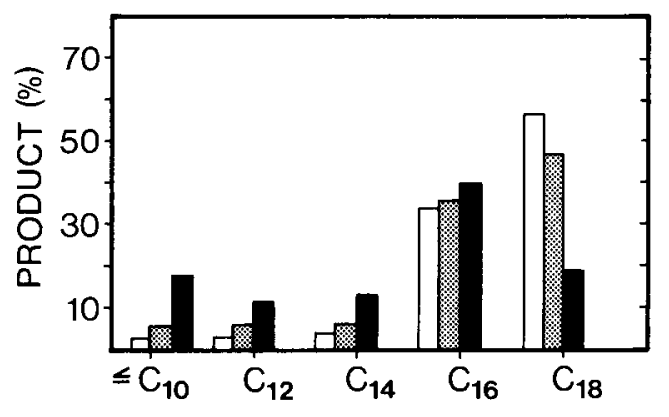

Figure 19. Effect of the acetyl-CoA concentration on the composition of the fatty acids synthesized by S-300 fas.

The assay for fas activity was carried out as specified in the legend for Figure 15. Acetyl-CoA concentrations employed; white bars $=5$ nmoles. dotted bars $=30$ nmoles and black bars $=120$ nmoles per assay. Distributions are based on a minimum of $23,000 \mathrm{cpm}$.

more likely that the ratio between malonyl-CoA and acetyl-CoA rather than the absolute amount of malonyl-CoA alone determines the fatty acid. product distribution. Our observations are analogous to those obtained with yeast (5) or animal

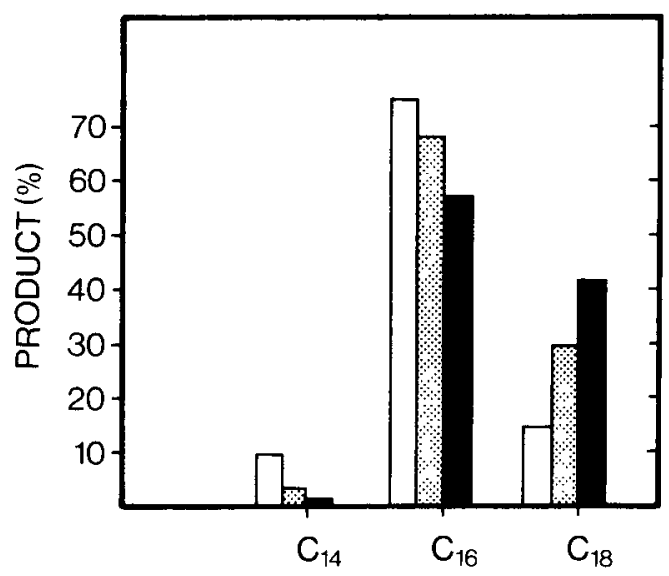

Figure 20. Effect of malonyl-CoA concentration on the composition of the fatty acids synthesized by S-300 fas.

The assay for fas activity was carried out as described in the legend to Figure 16. The amounts of malonyl-CoA used per experiment were; white bars $=25$, dotted bars $=100$ and black bars $=180$ nmoles per assay. Distributions are based on a minimum of $2.000 \mathrm{cpm}$. multifunctional enzymes $(8,18)$, but differs from those reported for the avocado (19) and potato tuber systems (23). The effect of pyridine nucleotide levels on product distribution is evident from the data in Figure 21. Low levels of pyridine nucleotides favor short chain acids while higher levels shift the pattern towards long chain fatty acids. No keto or unsaturated fatty acids were detected at low pyridine nucleotide levels. Whether mono- and poly-ketoacids actually are formed and subsequently broken down during the following base hydrolysis, could not be determined using the present analytical systems. The fatty acyl products and distribution thereof with barley ACP and E.coli ACP seem identical (results not presented), confirming the report of SimONı et al. (47) who made a similar comparison between E.coli and spinach ACPs. When the E.coli ACP concentration was varied from 10 to $100 \mu \mathrm{g}$ per assay the fatty acid product distribution remained reasonably constant, although the prominence of the shorter chains was increased at the higher ACP levels. Finally, changing the $\mathrm{pH}$ of the assay in the range 7.1-8.7 did not perturb the product composition. This result is different from that obtained with the potato tuber fas (23).

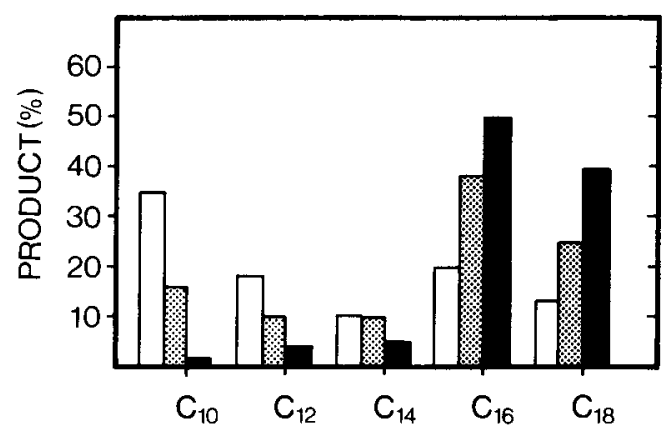

Figure 21. Effect of pyridine nucleotide concentration on the compositions of the fatty acids syntehsized by S-300 fas.

The assay for fas activity was carried out as described in legend to Figure 17. The combinations of NADPH and NADH were; white bars $=25$, dotted bars $=75$ and black bars $=500$ nmoles of each pyridine nucleotide per assay. Distribution are based on a minimum of $7,000 \mathrm{cpm}$. 


\section{DISCUSSION}

De novo fatty acid synthesis in the stroma of the barley chloroplast is carried out by a complex of enzymes termed fas. In a series of reactions the primer acetyl-CoA is elongated by seven or eight $\mathrm{C}_{2}$-units mediated by malonyl-CoA. Five of the component activities of barley chloroplast fas have been partially separated. $\left(\mathrm{NH}_{4}\right)_{2} \mathrm{SO}_{4}$ fractionation yielded $\mathrm{ACP}$, gel filtration and/or affinity chromatography allowed partial or complete severance of acetyl-CoA:ACP transacylase, malonyl-CoA:ACP transacylase, $\beta$-ketoacyl-ACP reductase and $\beta$-ketoacyl-ACP synthetase while gel filtration chromatography gave the S-300 fas. From our successful recombination experiments with separated fas components plus characterization of the S-300 fas preparation, we conclude that barley chloroplast fas is similar to the fas found in E. coli and to one of those in E. gracilis. In these systems all of the component enzyme activities have been shown to exist as discrete monofunctional polypeptides using conventional methods of protein purification $(1,15$, $21,42,53$ ). Although easily separable in vitro, the component activities of the E. coli fas are not likely to be randomly distributed in vivo within the bacterial cell. Rather, they are probably organized as a multienzyme complex which includes ACP (5). In the following discussion we use the definition of multienzyme complex given by KIRSCHNER and Bisswanger (31) which is based on the association of enzyme activities regardless of whether they are components of one or more polypeptides. In the former case it is a monofunctional multienzyme complex and in the latter case it is a multifunctional multienzyme complex. The suggested model is supported by the observation that while ACP interacts specifically and consecutively with acetylCoA:ACP transacylase, malonyl-CoA:transacylase, $\beta$-ketoacyl-ACP synthetase, $\beta$-ketoacyl$\mathrm{ACP}$ reductase, $\beta$-hydroxyacyl-ACP dehydrase and enoylacyl-ACP reductase, no free acyl-ACP intermediates are found in E. coli cells (5). ACP has been reported to be preferentially associated with the cell membrane (5). This association, however, must be quite loose as ACP is easily obtained from the soluble fraction and does not remain with the membrane fragments during isolation.

Presumably in vitro the E. coli, E. gracilis and barley chloroplast fases are also assembled into multienzyme complexes where the intermediates are retained within the complex during the complete reaction sequence. If they were not so organized, all of the intermediates of the reaction sequence would have to encounter the next component enzyme by free diffusion throught the incubation medium. One line of evidence supporting this contention comes from the similarity of the kinetic parameters of the ACP independent, multifunctional and the ACP dependent, monofunctional fases from $\mathrm{E}$. gracilis (14). The multienzyme complex model would also explain why fatty acid synthesis by the barley chloroplast fas only takes place above given protein concentrations. When in $\mathrm{E}$. gracilis the ACP dependent, monofunctional fas was preincubated with ACP prior to initiation of the fas reaction with malonyl-CoA, both a higher initial and maximal rate of fatty acid synthesis were observed (14). This was taken to indicate that ACP plays a very important role in organizing the enzymes of this ACP dependent fas. Similar results have recently been observed using the fas from soybean cotyledon chloroplasts (44). In marked contrast the fas from spinach chloroplasts was not activated by preincubation (44). The difference of the latter system from the others mentioned may indicate that the active form of the spinach chloroplast fas is a considerably more stable system. While the just cited results infer that the component activites of the named ACP dependent fases exist as multienzyme complexes in vitro, the physical forces involved in this process may differ. In E. gracilis an apparently very strong physical association prevented the severance of the $\beta$ ketoacyl-ACP synthetase and enoyl-ACP reductase activities by a gel filtration procedure similar to that employed for the barley chloroplast fas. Further kinetic studies using the isolated components purified to homogeniety have to be performed to conclusively determine the exact organizational form of the various ACP dependent fases.

Whereas the ACP component in bacteria, green algae and plant fases is readily dissociable from the other components, the amino acids of this entity are part of the multifunctional polypeptides composing these systems from animals, yeast and molds (35). ACP from the 
latter fases, which can only be released by proteolytic cleavage $(25,41)$, has a molecular weight that ranges from 6 to $16 \mathrm{kD}(25)$. These sizes are similar to that of ACP from plants $(9.5$ to $11.5 \mathrm{kD} ; 49)$, E. gracilis $(10.4 \mathrm{kD} ; 11)$ and bacteria ( 8.7 and $9.5 \mathrm{kD} ; 49)$. If the animal, yeast and mold fases are attacked by proteases during their isolation, a high molecular weight fas dependent upon ACP can result, as reported for example for M. smegmatis (2). Thus dependence upon ACP by a newly isolated fas cannot by itself serve to discriminate between a mono- and multifunctional, multienzyme fas complex.

An approximate total molecular weight of $609 \mathrm{kD}$ for the barley chloroplast, multienzyme fas complex can be calculated from the sum of the molecular weights of its monofunctional components. From present results: $125 \mathrm{kD}, \beta$ ketoacyl-ACP reductase; $92 \mathrm{kD}, \beta$-ketoacyl-ACP synthetase; $82 \mathrm{kD}$, acetyl-CoA:ACP transacylase; and $41 \mathrm{kD}$, malonyl-CoA:ACP transacylase. The molecular weights for the remaining polypeptides were approximated from $\mathrm{E}$. coli (25, 53): $9 \mathrm{kD}, \mathrm{ACP} ; 170 \mathrm{kD}, \beta$-hydroxyacyl$\mathrm{ACP}$ dehydrase and $90 \mathrm{kD}$ enoylacyl-ACP reductase. The $609 \mathrm{kD}$ value can be compared with the reported molecular weights of 400 to 590,2000 and $2300 \mathrm{kD}$ of the multifunctional, multienzyme fas complexes isolated from animals, M. smegmatis and yeasts, respectively (48). The animal fases are composed of two identical subunits $\left(\alpha_{2}\right)$, that from yeast of six copies of two non-identical subunits $\left(\alpha_{6} \beta_{6}\right)$ while that from $M$. smegmatis has been estimated to have six to eight copies of a single subunit $\left(\alpha_{6}\right.$ or $\left.\alpha_{8}\right)$.

Germinating peas $(3,4)$ and etiolated E. gracilis cells (30) are reported to contain both a soluble and a microsomal fas. The membrane bound fas from etiolated $E$. gracilis has been studied in great detail. It provides substrates for the acyl-CoA and aldehyde reductases that synthesize aldehydes, primary alcohols and esters which are the major lipid components of etiolated E. gracilis (30). Which fas synthesizes the membrane lipids of the etiolated E. gracilis cells has not been determined. The presently studied barley chloroplast fas indubitably has the capability to synthesize the $\mathrm{C}_{16}$ and $\mathrm{C}_{18}$ fatty acyl chains used in constructing the skeleton of the chloroplast membranes. Whether the same fas also provides the acyl precursors for the other lipids such as those of the cytoplasmic membranes and epicuticular waxes is unknown. Perhaps a membrane fas is involved. Thus far none of the conditions explored has induced this fas to make chains with more than 18 carbons in significant amounts. Whether this is due to our ignorance with regard to cofactors, specific substrates of effectors, or whether S-300 fas represents only part of a more extensive and/or compartmentalized lipid synthesizing machinery, including $\mathbf{C}_{18}$ to $\mathrm{C}_{32}$ elongases and membrane bound fases for example, will be a major concern of our continuing studies.

\section{ACKNOWLEDGEMENTS}

It is a pleasure to acknowledge the contribution of Dr. Penny von WetTstein-KnOwles for inspiring discussions and for critically reviewing the manuscript. We would like to thank Ms. Merete Petersen for excellent technical assistance. Thanks are also due to Ms. Nina RasmusSEN for drawing the figures.

\section{REFERENCES}

1. Alberts, A. W., P. W. Majerus, B. Talamo \& P. R. VAGELos: Acyl-carrier protein. II. Intermediary reactions of fatty acid synthesis. Biochemistry 3, 1563-1571 (1964)

2. Вцосн, K.: Control mechanisms for fatty acid synthesis in Mycobacterium smegmatis. Adv. Enzymol. 45, 1-84 (1977)

3. Bolton, P.\& J. L. HaRwood: Some characteristics of soluble fatty acid synthesis in germinating pea seeds. Biochim. Biophys. Acta 489, 15-24 (1977)

4. Bolton, P. \& J. L. Harwood: Fatty acid biosynthesis by a particulate preparation from germinating pea. Biochem. J. 168, 261-269 (1977)

5. Bosch, H. vaN DEN, J. R. WILliamson \& P. R. VAGELOS: Localization of acyl carrier protein in Escherichia coli. Nature 228, 338-341 (1970)

6. Bradford, M. M.: A rapid and sensitive method for the quantitation of microgram quantities of protein utilizing the principle of protein-dye binding. Anal. Biochem. 72. 248-254 (1976)

7. Brooks, J. L. \& P. K. Stumpf: Fat metabolism in higher plants. Properties of a soluble fatty acid synthesizing system from lettuce chloroplasts. Arch. Biochem. Biophys. 116, 108-116 (1966) 
8. CAREY, E. M. \& R. DILS: Fatty acid biosynthesis. Specificity for termination of fatty acid biosynthesis by fatty acid synthetase from lactatingrabbit mammary gland. Biochim. Biophys. Acta $210,388-399(1970)$

9. Corkey, B. E., M. Brandt, R. J. Williams \& J. R. Williamson: Assay of short-chain acyl Coenzyme $\mathrm{A}$ intermediates in tissue extracts by high-pressure liquid chromatography. Anal. Biochem. 118, 30-41 (1981)

10. Delo, J., M. L. Ernst-Fonberg \& K. Bloch: Fatty acid synthetases from Euglena gracilis. Arch. Biochem. Biophys. 143, 384-391 (1971)

11. DiNello, R. K. \& M. L. Ernst-Fonberg. Acyl Carrier Protein from Euglena gracilis. Meth. Enzymol XXXV, 110-114 (1975)

12. Eggerer, H. \& F. Lynen: Zur Biosynthese der Fettsäuren. Synthese und Eigenschaften von Smalonyl-Coenzym A. Biochem. Z. 335, 540547 (1962)

13. Ellman, G. L.: Tissue sulfhydryl groups. Arch. Biochem. Biophys. 82, 70-77 (1959)

14. ERnst-Fonberg, M. L.: Fatty acid synthetase activity in Euglena gracilis variety bacillarius. Characterization of an acyl carrier protein dependent system. Biochemistry $12,2449-2455$ (1973)

15. Garwin, J. L., A. L. Klages \& J. E. Cronan: Structural, enzymatic, and genetic studies of $\beta$ ketoacyl-acyl carrier protein synthetases I and II of Escherichia coli. J. Biol. Chem. 255, 11949 11956 (1980)

16. Goldberg, I. \& K. Bloch: Fatty acid synthetases in Euglena gracilis. J. Biol. Chem. 247, 73497357 (1972)

17. Goldman, P., A. W. Alberts \& P. R. Vagelos: The condensation reaction of fatty acid synthesis. J. Biol. Chem. 238, 3579-3583 (1963)

18. Hansen, H. J. M., E. M. Carey \& R. Dils: Fatty acid biosynthesis. Substrate control of chainlength of products synthesised by rat liver fatty acid synthetase. Biochim. Biophys. Acta 210 . 400-410 (1970)

19. Harwood, J. L. \& P. K. StumpF: Fat metabolism in higher plants. Palmitic and stearic synthesis by an avocado supernatant system. Arch. Biochem. Biophys. 148, 282-290 (1972)

20. HARWOOD, J. L.: The synthesis of acyl lipids in plant tissues. Prog. Lipid Res. 18, 55-86 (1979)

21. Hendren, R. W. \& K. Bloch: Fatty acid synthetases from Euglena gracilis. Separation of component activities of the ACP-dependent fatty acid synthetase and partial purification of the $\beta$ ketoacyl-ACP synthetase. J. Biol. Chem. 255, 1504-1508 (1980)
22. Higgins, M. J. P. \& R. G. O. KeKwick: An investigation into the role of malonyl-CoA in isoprenoid biosynthesis. Biochem. J. 134, 295310 (1973)

23. Huang, K. P. \& P. K. Stumpf: Fat metabolism in higher plants. Fatty acid synthesis by a soluble fatty acid synthetase from Solanum tuberosum. Arch. Biochem. Biophys. 143, 412-427 (1971)

24. JaWorski, J. G., E. E. Goldschmidt \& P. K. Stump: Fat metabolism in higher plants. Properties of the palmityl acyl carrier protein: Stearyl acyl carrier protein elongation system in maturing safflower seed extracts. Arch. Biochem. Biophys. 163. 769-776 (1974)

25. JENIK, R. A.: Studies on the isolation and purification of fatty acid synthetase complexes and their structural organization. $\mathrm{Ph}$. $\mathrm{D}$. Thesis University of Wisconsin. Madison, U.S.A. (1980)

26. Jende-Strid, B. \& B. L. Møller: Analysis of proanthocyanidins in wild-type and mutant barley (Hordeum vulgare L.). Carlsberg Res. Commun. 46, 53-64 (1981)

27. Kannangara, C. G., S. P. Gough, B. Hansen, J. N. Rasmussen \& D. J. Simpson: A homogenizer with replaceable razor blades for bulk isolation of active barley plastids. Carlsberg Res. Commun. 42, 431-440 (1977)

28. Kannangara, C. G. \& S. P. Gough: Biosynthesis of $\Delta$-aminolevulinate in greening barley leaves: Glutamate 1-semialdehyde aminotransferase. Carlsberg Res. Commun. 43, 185-194 (1978)

29. Kannangara, C. G., S. P. Gough, \& C. Girnth: $\Delta$-Aminolevulinate synthesis in greening barley. 2. Purification of enzymes. In: Photosynthesis V. Chloroplast Development. G. Akoyunoglou, ed.. Balaban International Science Services, Philadelphia, Pa., pp. 117-127 (1981)

30. Khan, A. A. \& P. E. Kolattukudy: Solubilization of fatty acid synthetase, acyl-CoA reductase, and fatty acyl-CoA alcohol transacylase from the microsomes of Euglena gracilis. Arch. Biochem. Biophys. 170, 400-408 (1975)

31. Kirschner, K. \& H. Bisswanger: Multifunctional proteins. Ann. Rev. Biochem. 45, 141-163 (1976)

32. Kuhn, D. N., M. Knauf \& P. K. StumpF: Subcellular localization of Acetyl-CoA synthetase in leaf protoplasts of Spinacia oleracea. Arch. Biochem. Biophys. 209, 441-450 (1981)

33. Locasio, G. A., H. A. Tigier \& A. M. del C. BATLLE: Estimation of molecular weights by agarose gel filtration. J. Chrom. 40, 453-457 (1969). 
34. Lowry, O. H., N. J. Rosebrough, A. L. Farr \& R. J. Randall: Protein measurement with the folin phenol reagent. J. Biol. Chem. 193, 265275 (1951)

35. LYNEN, F.: On the structure of fatty acid synthetase of yeast. Eur. J. Biochem. 112, 431442 (1980)

36. Majerus, P. W., A. W. Alberts \& P. R. VAGELOS: Acyl carrier protein from Escherichia coli. Methods of Enz. XIV, 43-50 (1969)

37. Mikkelsen, J. D.: Structure and biosynthesis of $\beta$-diketones in barley spike epicuticular wax. Carlsberg Res. Commun. 44, 133-147 (1979)

38. Nikolau, B. J., J. C. Hawke \& C. R. Slack: Acetyl-Coenzyme A carboxylase in maize leaves. Arch. Biochem. Biophys. 211, 605-612 (1981)

39. Noyes, B. E. \& R. A. Bradshaw: L-3hydroxyacyl Coenzyme A dehydrogenase from pig heart muscle. Purification and properties. J. Biol. Chem. 248, 3052-3059 (1973)

40. PackTer, N. M. \& P. K. StumpF: Fat metabolism in higher plants. The effect of cerulenin on the synthesis of medium- and long-chain acids in leaf tissue. Arch. Biochem. Biophys. 167.655667 (1975)

41. Puri, R. N. \& J. W. Porter: Isolation of thioesterase and acyl carrier protein activities liberated by elastase digestion of pigeon liver fatty acid synthetase. Biochem. Biophys. Res. Commun. 100, 1010-1016 (1981)

42. Ruch, F. E. \& P. R. VAgelos: The isolation and general properties of Escherichia coli malonyl Coenzyme A-acyl carrier protein transacylase. J. Biol. Chem. 248, 8086-8094 (1973)

43. Rutkoski, A. \& J, G. JAworsKI: An improved synthesis of malonyl-Coenzyme A. Anal. Biochem. 91, 370-373 (1978)

44. Rutkoskı, A. \& J. G. JAwOrSkı: Fatty acid synthetase from chloroplasts of soybean cotyledons: ACP activation and $\mathrm{CoA}$ inhibition. Biochem. Biophys. Res. Commun. 84, 428-433 (1978)

45. Salto, K., A. Kawaguchi, S. Okuda, Y. Seyama, T. Yamakawa, Y. Nakamura \& M.
YamadA: Stereospecificity of hydrogen transfer by pyridine nucleotide-dependent enoyl reductases in fatty acid synthesis: Studies with enzymes obtained from developing castor bean seeds and Chlorella vulgaris. Plant \& Cell Physiol. 21, 919 (1980)

46. Simon, E. J. \& D. Shemin: The preparation of Ssuccinyl Coenzyme A. J. Amer. Chem. Soc. 75, 2520-2521 (1953)

47. Simoni, R. D., R. S. Criddle \& P. K. Stumpf: Fat metabolism in higher plants. Purification and properties of plant and bacterial acyl carrier proteins. J. Biol. Chem. 242, 573-581 (1967)

48. Sмiтh, S.: Mechanism of chain length determination in biosynthesis of milk fatty acids. J. Dairy Sci. 63, 337-352 (1980)

49. StumpF, P. K.: Biosynthesis of saturated and unsaturated fatty acids. In: The Biochemistry of Plants. A Comprehensive Treatise. P. K. Stumpf \& E. E. Conn. eds. Academic Press, New York, pp. 177-204 (1980)

50. Sumper, M., D. Oesterhelt, C. Riepertinger \& F. LYNen: Die Synthese verschiedener Carbonsäuren durch den Multienzymkomplex Fettsäuresynthese aus Hefe und die Erklarung ihrer Bildung. European J. Biochem. 10, 377-387 (1969)

51. Wakil, S. J., E. L. Pugh \& F. Sauer: The mechanism of fatty acid synthesis. Proc. Natl. Acad. Sci. 52, 106-114 (1964)

52. Wealre, P. J. \& R. G. O. Kekwick: The fractionation of the fatty acid synthetase activities of avocado mesocarp plastids. Biochem. J. $146,439-445$ (1975)

53. Weeks, G. \& S. J. Wakil: Studies on the mechanism of fatty acid synthesis. Preparation and general properties of the enoyl acyl carrier protein reductases from Escherichia coli. J. Biol. Chem. 243, 1180-1189 (1968)

54. White, H. B., O. Mitsuhashi \& K. Bloch: Pyridine nucleotide requirements of fatty acid synthetases. J. Biol. Chem. 246, 475I-4754 (1971) 